\title{
Valorization of Spent Coffee Grounds into Biofuels and Value-Added Products:
}

\section{Pathway towards Integrated Bio-refinery}

A.E. Atabani ${ }^{1 *}$, Ala'a H. Al-Muhtaseb ${ }^{2 *}$, Gopalakrishnan Kumar ${ }^{3 *}$, Ganesh Dattatrya Saratale $^{4}$, Muhammad Aslam ${ }^{5}$, Hassnain Abbas Khan ${ }^{6}$, Zafar Said $^{7}$, Eyas Mahmoud ${ }^{8}$

${ }^{1}$ Green Processing, Bioremediation, and Alternative Energies Research Group, Faculty of Environment and Labour Safety, Ton Duc Thang University, Ho Chi Minh City, Vietnam

${ }^{2}$ Department of Petroleum and Chemical Engineering, College of Engineering, Sultan Qaboos University, Muscat-Oman

${ }^{3}$ Institute of Chemistry, Bioscience and Environmental Engineering, Faculty of Science and Technology, University of Stavanger, Box 8600 Forus, 4036 Stavanger, Norway

${ }^{4}$ Department of Food Science and Biotechnology, Dongguk University - Seoul, Ilsandong-gu, Goyang-si, Gyeonggido 10326, Republic of Korea

${ }^{5}$ Department of Chemical Engineering, COMSATS University Islamabad (CUI), Lahore Campus, Defense Road, Off Raiwind Road, Lahore, Pakistan

${ }^{6}$ Clean Combustion Research Center, Division of Physical Sciences and Engineering, King

Abdullah University of Science and Technology (KAUST), Thuwal, 23955-6900 Saudi Arabia

${ }^{7}$ Sustainable and Renewable Energy Engineering, College of Engineering, University of Sharjah, PO Box: 27272, Sharjah, United Arab Emirates

${ }^{8}$ Department of Chemical and Petroleum Engineering, College of Engineering, United Arab Emirates University, PO Box: 15551, Al Ain, United Arab Emirates

\section{*Corresponding authors:}

\section{A.E. Atabani}

Email: abdulaziz.atabani@tdtu.edu.vn.

Ala'a H. Al-Muhtaseb

Email: muhtaseb@squ.edu.om.

Gopalakrishnan Kumar

Email: gopalakrishnanchml@gmail.com, gopalakrishnan.kumar@uis.no. 


\section{Graphical Abstract}

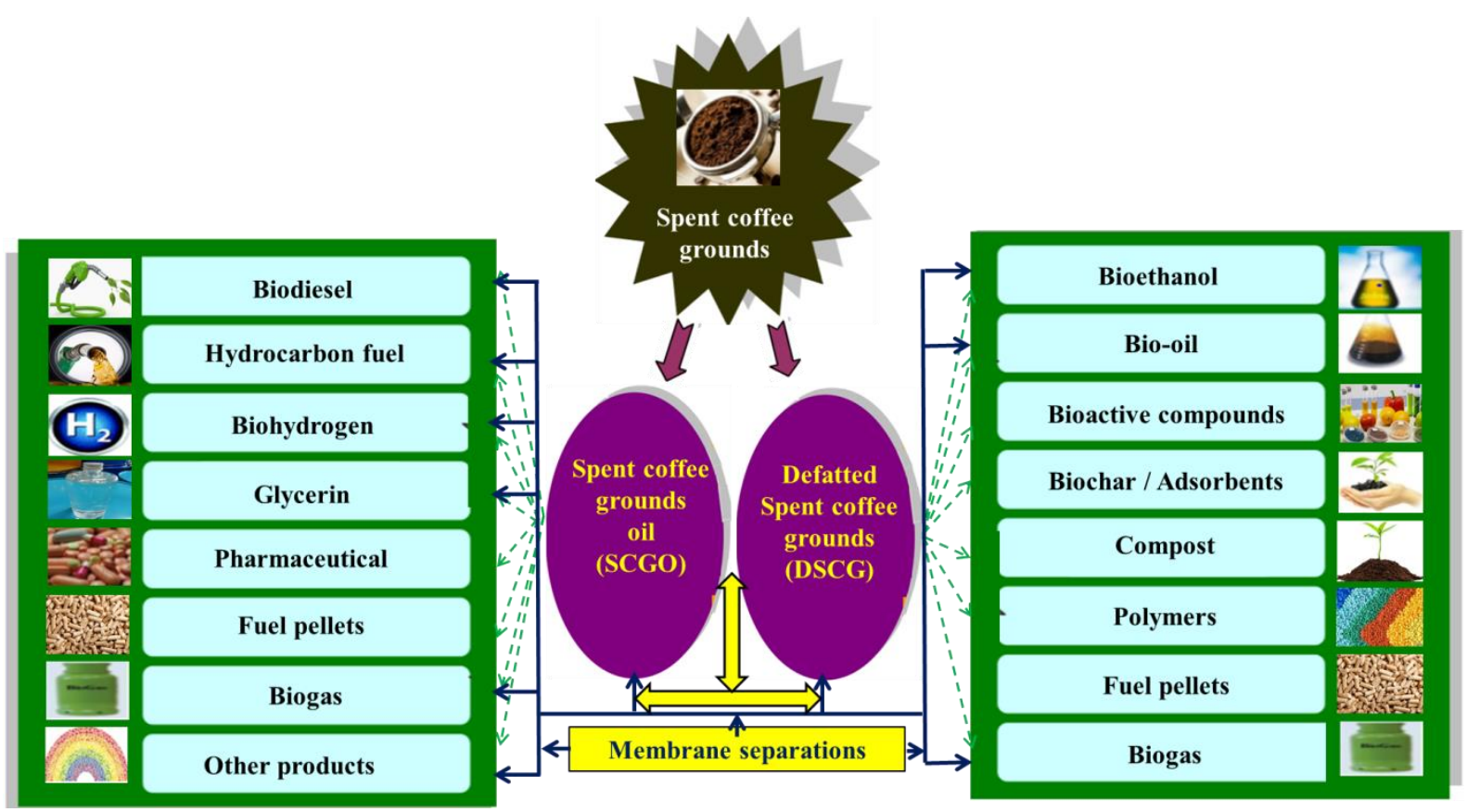




\begin{abstract}
Coffee is the second largest traded commodity after petroleum and the second most popular beverage after water. This big industry is believed to generate huge amount of waste with spent coffee grounds (SCGs) represents one of the main by-products. Recycling of such waste to fuels and value-added products through bio-refineries is a promising way to solve the problem of many countries that face daily challenges and heavy cost in waste disposal. This review aims to shadow the light on SCGs recycling potential in which over 230 published papers on SCGs recycling topic were gathered and discussed. Various opportunities to produce biofuels such as biodiesel, biogas, bioethanol, bio-oil and fuel pellets besides valueadded products such as bioactive compounds, adsorbents, polymers, nanocomposites, and compost were discussed. Moreover, the potential of membrane technology related to various processes of biorefining, separation and purification in the proposed SCG-integrated biorefinery are presented. Based on the presented review, it is obvious that recycling of SCGs offers many worthwhile options to policymakers that can contribute towards huge financial saving on taxpayers of running and maintaining landfills besides saving the environment from harmful emissions. In conclusion, this review emphasizes that SCG-integrated biorefineries to produce different types of biofuels and value-added products are a very promising approach that shall be economically more scrutinized in the foreseen future.
\end{abstract}

Keywords: Recycling, Spent coffee grounds, Biofuels, Value-added products, Bio-refinery. 


\section{Nomenclature}

\begin{tabular}{|c|c|c|c|}
\hline AV & Acid value & HDF & Hydrotreated diesel fraction \\
\hline But & Butanol & $\mathrm{HDO}$ & Hydrodeoxygenation \\
\hline $\mathrm{BHD}$ & Bio-hydrogenated diesel & HRT & Hydraulic retention time \\
\hline $\mathrm{CH}$ & Coffee husks & HTL & Hydrothermal liquefaction \\
\hline $\mathrm{CI}$ & Compression ignition & HHV & Higher heating value \\
\hline CIME & Calophyllum inophyllum methyl ester & IV & Iodine value \\
\hline $\mathrm{CN}$ & Cetane number & $\mathrm{KOH}$ & Potassium hydroxide \\
\hline COD & Chemical oxygen demand & KV & Kinematic viscosity \\
\hline $\mathrm{CP}$ & Cloud point & LHV & Lower heating value \\
\hline $\mathrm{CW}$ & Coffee waste & LCSF & Long chain saturated factor \\
\hline CS & Coffee silverskin & DME & Dimethyl ether \\
\hline DSC & Differential scanning calorimetry & MLR & Methanol-lipid ratio (mL-methanol/g-lipid) \\
\hline DSCG & Defatted spent coffee grounds & $\mathrm{NaOH}$ & Sodium hydroxide \\
\hline D100 & Euro diesel & OS & Oxidation stability \\
\hline $\mathrm{DCO}$ & Decarbonylation & Pen & Pentanol \\
\hline $\mathrm{DCO}_{2}$ & Decarboxylation & PHAs & polyhydroxyalkanoates \\
\hline DU & Degree of unsaturation & PMHS & Polymethylhydrosiloxane \\
\hline FAC & Fatty acid composition & PP & Pour point \\
\hline FFA & Free fatty acids & SCG & Spent coffee grounds \\
\hline FAME & Fatty acid methyl esters & SCGO & Spent coffee grounds oil \\
\hline FAEE & Fatty acid ethyl ester & SCGOME & Spent coffee grounds oil methyl ester \\
\hline FCG & Fresh coffee grounds & SFE & Supercritical fluid extraction \\
\hline FP & Flashpoint & $\mathrm{SN}$ & Saponification number \\
\hline FW & Food waste & STW & Spent tea waste \\
\hline GC & Gas chromatography & TGA & Thermogravimetric analysis \\
\hline GC-MC & Gas chromatography-mass spectrometry & TG-FTIR & $\begin{array}{l}\text { Thermogravimetric analyzer coupled to a Fourier transform } \\
\text { infrared spectrometer }\end{array}$ \\
\hline $\mathrm{H}_{2} \mathrm{SO}_{4}$ & Sulfuric acid & WCO & Waste cooking oil \\
\hline HCL & Hydrochloric acid & XRD & X-ray diffraction \\
\hline
\end{tabular}




\subsection{Overview of waste and recycling}

The world is producing a huge amount of waste on a daily basis. These mainly include municipal, food, beverage, agricultural, and industrial wastes. Dumping these wastes directly to the landfills is very harmful if not disposed or recycled appropriately as they are toxic and may cause serious environmental problems [1]. This is due to the existence of some organic compounds that demand excessive amounts of oxygen to be degraded $[2,3]$. Moreover, direct disposal of waste without assessing its recycling potential may contribute towards huge financial cost on taxpayers who run and maintain landfills [4]. Recycling of waste to energy and value-added products is one effective way to solve the problem of many countries that face a serious challenge in dealing with huge amount of waste generated daily due to their increasing population, industrial growth, and human consumption. Waste recycling offers many environmental, social and financial benefits [5]. It also contributes to producing biofuels and value-added products without the need for growing plants (edible or non-edible) or converting food (edible oils) to fuel [6]. Fig. 1 highlighted an effective mechanism of recycling waste into products [4]. This pathway can be organized in a sequential, systematic and consistent manner whereby the output of one process becomes the input for another process, thus avoid wasting secondary materials [7].

In this regard, restaurants and beverage shops generate a huge amount of waste such as waste cooking oil (WCO), spent coffee grounds (SCG), food waste (FW), spent tea waste (STW), etc. Among them, SCG is a valuable waste due to its promising characteristics. Direct disposal of SCG to landfills can emit methane, carbon dioxide and greenhouse gases that contribute to global warming [4]. Thus, creating proper waste management plans that are consistent with existing national regulation are much needed [8].

This review article aims to shadow the light on SCG recycling potential. 233 published papers on the topic were gathered to introduce various opportunities to produce biofuels such as biodiesel, biogas, bioethanol, bio-oil and fuel pellets besides value-added products such as bioactive compounds, adsorbents, polymers, nanocomposites, and compost. Moreover, membrane technology for SCG-integrated biorefinery was also introduced in this review. Finally, the current review emphasizes the potential of SCG recycling in which a proposed SCG bio-refinery with many options was presented at the end of the paper. This review article was also enriched with many data that highlighted different important characteristics of SCG. 


\subsection{Overview of coffee and coffee industry}

Coffee was discovered in Ethiopia 1000 years ago [9]. Coffee tree belongs to the family Rubiaceae. Coffea genus comprises 103 species which are divided into subgenus Coffea and subgenus Baracoffea. The subgenus Coffea includes the species that used in coffee production [10]. Coffea arabica (arabica coffee) and Coffea canephora (robusta coffee) have been classified as the most economically and commercially used among others $[11,12]$. Coffea canephora is less susceptible to disease and can be grown in lower altitude and warmer climate. However, Coffea Arabica represents 75-80\% of the worldwide coffee production [13, 14]. Fig. 2 shows coffee fruit(berry/cherry) [15]. The fruit (berry/cherry) can be divided into two main parts, the pericarp and the bean [16]. The pericarp consists of a smooth, tough outer skin usually green in unripe fruits and turns red-violet or deep red when ripe (even yellow or orange in particular genotypes) [17]. The pericarp covers a soft yellowish, fibrous and sweet pulp (outer mesocarp), a highly hydrated layer of mucilage (the pectin layer), and a thin endocarp (the parchment). The bean comprises silver skin, an endosperm, and coffee seed [13, 17]. The fruit (berry/cherry) usually bears two coffee beans [18] (Fig. 2). Coffee bean size varies; however, their average size $10 \mathrm{~mm}$ long and $6 \mathrm{~mm}$ wide [16]. Coffee is grown in about 80 countries [19] with Brazil and Vietnam represent the major coffee producing and exporting countries around the world (35\% and 15\% respectively) (Fig. 3) [20, 21]. The main coffeebrewing methods are boiling (Greek/Turkish, Scandinavian, etc., with caffeine content less than $50 \mathrm{mg} \mathrm{cup}^{-1}$ ), the filter (filter coffee: caffeine content, 100-150 $\mathrm{mg} \mathrm{cup}^{-1}$ ), the dissolving (instant/soluble coffee: caffeine content, 65-100 $\mathrm{mg} \mathrm{cup}^{-1}$ ), and the pressure method (espresso: caffeine content, $60 \mathrm{mg} \mathrm{cup}^{-1}$ ). Due to its refreshing properties, millions of cups of coffee are consumed every day worldwide, and thus coffee is the most important food commodity, the second most popular beverage after water and the second largest traded commodity after petroleum [22-25]. Between 2015-2016, more than 9 million tons of coffee products were consumed worldwide (according to International Coffee Organization) resulted in an estimated 3.6 million tons of SCG [26, 27]. In South Korea, a total of 118.8 million $\mathrm{kg}$ of coffee were consumed in 2015-2016 compared to 104.9 million kg in 2012-2013 representing annual growth of $4.2 \%$ [28]. In Malaysia, a total of 650 thousand bags (60 kg each) were consumed in 2013/14 increasing by 30\% from the previous year [29]. Australians consume 6 billion cups of coffee every year [4]. Most of the world's developed countries have the highest per capita coffee consumption with Finland leading the world (11.9 kg per capita) followed by Norway (8.63 kg per capita), Denmark (8.6 kg per capita) and Austria (8.58 kg 
per capita) [26, 30]. Coffee beverage has proven to offer many health benefits [3] such as reducing the risk of cancer (liver, kidney, oral, breast and colorectal), cell protection from damage, Neurodegenerative diseases (Parkinson, Alzheimer, and Amyotrophic lateral sclerosis) and cardiovascular disorders [31].

Coffee industry generates large quantities of waste that are either directly disposed in landfills or used as compost [7]. Therefore, proper waste management is needed [23] with SCG, coffee silverskin (CS) and coffee husks $(\mathrm{CH})$ represent the main by-products [32]. According to Kourmentza et al., [9], SCG are available at low-cost of $0.061 \mathrm{USD} / \mathrm{kg}$ in Colombia. SCG is considered as the key culprit for contaminating other waste streams [33]. According to [4], coffee industry generates around $6 \mathrm{Mt}$ of waste per year. The UK produces 500,000 tons of SCG each year [34]. As a result, large amounts of dark-coloured waste are generated as 650 $\mathrm{kg}$ of SCG are generated from 1 ton of green coffee [23, 32]. Moreover, coffee wastewater generated from this industry contains dissolved and suspended organic carbon with average chemical oxygen demand (COD) between 18,000-30,000 milligrams per litre that can also be valorized in many useful ways among which anaerobic digestion (AD) to produce biogas is the most viable approach $[\mathbf{3 5}, \mathbf{3 6}]$. According to Tucker [36], wastewater treatment strategy has resulted in generating 200,000 $\mathrm{kW}$ at the CISA pilot site, Diriamba, Nicaragua using biogas plant with annual savings of $\$ 40,000$.

\subsection{Overview of SCG recycling potential}

SCG is the solid residue that is left over after the preparation of an instant coffee beverage with fine particle size, high organic load, and humidity [37]. It represents one of the largest by-products of soluble coffee processing industries representing 40-45\% of the fresh weight of coffee cherry [38-41]. Fig. 4 shows the images of freshly brewed SCG, dried SCG and defatted spent coffee grounds (DSCG) (after lipids removal/extraction) [42].

SCG has been reported to contain large amounts of organic compounds (more than 1000 individual compounds) such as proteins, carbohydrates, tannins, fibres, caffeine, cellulose, non-protein nitrogenous, fatty acids, amino acids, polyphenols, minerals lignin and polysaccharides [43, 44] namely; galactomannans and arabinogalactans [45-47]. Besides more than 700 volatile compounds that remain insoluble and unextractable in SCG during the thermal water extraction process and thus can be valorized in different ways. These components have been proven to possess high quality, organic content and energy content and superior physical properties that must be exploited in an appropriate manner. SCG can be 
recycled in different ways to produce various types of biofuels such as biohydrogen [6], biobutanol [1], biodiesel [5, 6, 20, 21, 28, 30, 48-82], fuel pellets [5-7, 51, 65, 66, 79, 83-89], bio-oil $[62,90-100]$, bioethanol $[53,59,79,101,102]$, biogas [103-111] and hydrocarbon fuels [112, 113] or value-added products such as bioactive compounds for food, pharmaceutical, cosmetic and chemical industries $[2,29,40,114-130]$ and antioxidants and anti-tumor activities $[3,14,26,45,131-152]$, adsorbents $[7,32,153-166]$, composting [167, 168], co-composting [169-171], vermicomposting [172, 173], nanocomposites [174], biopolymers [175-178], creams-scrubs, soaps and detergents [7], odor control [7], textile [41], facile preparation of pyrolytic carbon as anode in sodium-ion battery [179], inks and screen painting [7], yarn [7] and pulp and paper production [1, 7]. SCG has also been reported to possess functional properties such as water holding capacity (WHC $\sim 5.7 \mathrm{~g}$ water/g dry SCGs), oil holding capacity (OHC $5.2 \mathrm{~g}$ oil/g dry SCGs), emulsifying activity (54.7\%) and emulsion stability (92.4\%) [25]. An early study conducted by Givens and Barber [180], indicated that SCGs are worthless as a ruminant feed. Simões and Nunes [43] reported that polysaccharides; galactomannans and arabinogalactans are polymers that can be used as dietary fibre and present immune-stimulatory activity. This is also a useful resource for the food industry [40]. An interesting study conducted by Go et al., [181] proposed a way to valorize SCG in which it was first hydrolyzed with sulfuric acid to obtain sugar that can be fermented to bioethanol followed by extracting the lipids from the hydrolyzed SCG known as spent coffee grounds oil (SCGO) to produce biodiesel and glycerin. The DSCG was then proposed for the use either as fuel pellet or soil amendment agent. Alternatively, Kondamudi et al., [6] proposed to extract SCGO followed by converting it to spent coffee grounds oil methyl ester (SCGOME) (biodiesel) while glycerin can be further processed into biohydrogen. DSCG can be then hydrolyzed to produce bioethanol while the remained solid residue can be utilized as fuel pellets. Another pathway proposed by $[\mathbf{5 2}, \mathbf{5 3}, \mathbf{6 6}]$ suggested the utilization of glycerin and the solid residue of DSCG after hydrolysis process as fuel pellets instead of biohydrogen production from glycerin. Preliminary calculations conducted by Kondamudi et al., [6] indicated that converting SCGO to SCGOME beside utilizing SCG left after oil extraction (DSCG) as fuel pellets can yield an annual profit of more than $\$ 8$ million in the United States alone (considering only the waste generated by Starbucks stores). Fig. 5 shows the growing number of publications on the coffee industry recycling potential since 1983. Although this figure does not cover all published work on this topic. However, it is obvious that SCG recycling has got much attention especially in the past 8 years (2011 
onwards). The following chapters will highlight all recycling potentials of SCG to both biofuels and value-added products with emphasize on biofuels production opportunities.

\subsection{Valorization of SCG into biofuels}

\subsection{Biodiesel}

Coffee produces more oil per unit of land area than other traditional biodiesel crops with 386 $\mathrm{kg} / \mathrm{ha}$ compared to $375 \mathrm{~kg} / \mathrm{ha}$ for soybean [37]. It has been reported that $90.2 \%$ of lipids remain in SCG [8]. Processing the oil extracted from SCGs known as SCGO (brownish colour with concentrated coffee smell) to biodiesel (SCGOME) has been recently investigated in many publications $[5,6,20,21,28,30,48-82]$. Table 1 shows the advantages and disadvantages of biodiesel production from SCGO compared to other wastes $[\mathbf{5 , 6 , 7 5 ]}$. SCGO has higher stability and cost-effective than other waste sources available to date $[\mathbf{5 , 6}$. SCGO (represented as triolein) $\left(\mathrm{C}_{57} \mathrm{H}_{104} \mathrm{O}_{6}\right)$ can be transesterified to methyl oleate $\left(\mathrm{C}_{19} \mathrm{H}_{36} \mathrm{O}_{2}\right)$ and glycerol $\left(\mathrm{C}_{3} \mathrm{H}_{8} \mathrm{O}_{3}\right)$ by the following reaction [30]:

$\mathrm{C}_{57} \mathrm{H}_{104} \mathrm{O}_{6}+3 \mathrm{CH}_{3} \mathrm{OH} \rightarrow 3 \mathrm{C}_{19} \mathrm{H}_{36} \mathrm{O}_{2}+\mathrm{C}_{3} \mathrm{H}_{8} \mathrm{O}_{3}$

Compared to fresh coffee grounds (FCG), biodiesel from SCG does not contain caffeine that may increase $\mathrm{NO}_{\mathrm{x}}$ emissions. For instance, addition of $130 \mathrm{mg}$ of caffeine to $100 \mathrm{~g}$ of coffee sample produces around $150 \mathrm{mg} / \mathrm{kg}$ of $\mathrm{NO}_{\mathrm{x}}$ upon fuel combustion. This value is almost double the Euro 6 standard [20]. Production of biodiesel from SCG could add approximately 340 million gallons of biodiesel to the world's fuel supply per annum [49]. Another pathway proposed that SCGO to be converted either into fatty acid methyl ester (FAME) or fatty acid ethyl ester (FAEE) via non-catalytic transesterification process which shows high tolerance to both FFA moisture content followed by converting DSCG to bioethanol. Following this pathway, the production of FAEE from bioethanol may increases the renewability of SCG industry $[6,53,59]$. On the other hand, DSCG has been also proposed as purification material (activated carbon) to purify SCGOME [78] or to be further processed into bio-oil and bio-char by slow pyrolysis [62]. DSCG can be also used as fuel pellets in pure form [6] or mixed with glycerin (a by-product of biodiesel reaction) as addition of glycerin may enhance the combination of biomass particles besides increasing its heating value [66]. DSCG can be also used as compost as it has excellent $\mathrm{C} / \mathrm{N}$ ratio (Table 9).

Different types of non-polar solvents such as hexane $[\mathbf{5}, \mathbf{6 , 2 1}, \mathbf{2 7}, \mathbf{2 8}, \mathbf{4 2}, \mathbf{4 8}, \mathbf{5 0}, \mathbf{5 2}, \mathbf{5 3}, \mathbf{5 9}$, 62, 64-66, 71, 78, 80, 151, 182-185], toluene, chloroform and n-pentane $[64,186]$, ethyl 
acetate [27], n-octane and n-heptane [50], dichloromethane and diethyl ether [6] and dimethyl ether (DME) [70] and polar solvents such as iso-propanol, 1-butanol, ethanol, and acetone $[42,50,64,101,151,185,186]$ have been employed to extract SCGO. The antioxidant activities of SCGO extracted by polar solvents were reported to be higher than that of SCGO extracted by non-polar solvents. However, these values decreased by one third during biodiesel production process [151].

Other extraction methods of two-phase oil extraction have been reported in [187], ultrasoundassisted solvent extraction has been reported in [59], and supercritical fluid extraction (SFE) using $\mathrm{CO}_{2}$ has been reported in $[44,184,188-190]$ achieving 0.61-0.81 of $n$-hexane soxhlet extraction value [189]. A comparison among these methods revealed some drawbacks of soxhlet extraction and SFE along with some advantages of ultrasound-assisted solvent extraction method. Soxhlet oil extraction method is a relatively time-consuming process that requires a larger amount of solvent and energy to complete the extraction besides having low productivity. Moreover, SFE requires feedstock with very low water content besides the process requires high temperature and pressure and thus high energy demand. SFE also requires highly qualified labour [7].

On the other hand, ultrasound-assisted solvent extraction has been effectively applied in the extraction of some oils with the ability to enhance the oil extraction from feedstocks having either low or high moisture contents and at a low energy cost [59]. Moreover, some solvents such as hexane are classified as hazardous air pollutants as they cause ozone formation at the ground level which consequently forms smog [191]. Sakuragi et al., [70] reported the use of liquefied dimethyl ether (DME) as environmentally friendly, energy saving and low boiling solvent for oil extraction. The oil content of SCG was satisfactory $(16.8 \pm 1 \%)$. The study also indicated that SCG has a higher oil content than other wastes such as soybean cake $(0.97 \pm 0.05 \%)$ and rapeseed cake $(2.6 \pm 0.2)$ respectively. Couto et al., [190] reported that utilization of ethanol as a co-solvent at ethanol: $\mathrm{CO}_{2}$ mass ratio of 6.5:93.5 (w/w), $20 \mathrm{MPa}$ and $323 \mathrm{~K}$ achieved oil yield of $19.4 \%$ higher than without ethanol $(13.1 \%)$ at the same pressure and temperature and higher than soxhlet extraction with n-hexane (18.3\%). Mechanical extraction using hydraulic ram pressing and screw press has been reported in [192] and applying pressure with minimum quantities of solvents (ether or ethyl alcohol) that can be recycled back has been reported in [7]. This method has been developed at Università di Napoli Federico II, Italy. Table 2 highlights the oil content of SCG obtained from various resources $[5,6,20,21,28,42,44,48,50,52,54,56,59,61,64-70,77,78,80,82,113,151$, 
176, 183, 184, 188-190]. Variations in oil content are attributed to the type of extraction process, solvent used, time, temperature, liquid-solid ratio (LSR) and conditions of SCG. Liquid-solid ratio (LSR) has been reported to be the main parameter that affects the lipid extraction from SCG [28].

The results of acid value (AV) (mg KOH/ g oil) of SCGO reported in literature are tabulated in Table 3 [5, 21, 50, 52-54, 56, 59, 61, 62, 64-67, 74, 80, 82, 113, 151]. The variations in AV can be attributed to the prolonged storage duration of SCG especially at high storage temperature $\left(25-40{ }^{\circ} \mathrm{C}\right)$ and moisture content $(11.8 \%)$ which increase the AV of SCGO [183]. Since SCGO has been reported to have relatively high AV (Table 3) and as SCG has good HHV (Table 7), it has been proposed that SCG to be directly combusted in boilers or processed into other value-added products such as fertilizer as its rich in nitrogen (Table 8) [51]. Another recent study suggested the concept of pre-blending in which SCGO can be blended with other oils that have low AV to reduce its high acidity prior to biodiesel production [81].

SCGO has been proposed to improve the oxidation stability of biodiesel obtained from other feedstocks by three main approaches namely, blending SCGO with other oils at different percentages [81, 151], soaking powder of SCG in the reaction mixture during biodiesel production process or adding methanol extracts from SCG. All approaches were reported to remarkably improve the oxidation stability of biodiesel obtained from waste rapeseed from 1 to $3 \mathrm{~h}$, besides methods 2) and 3) being simple [151].

The main feature in SCGOME is that it has a low degree of unsaturation (DU) with high longchain saturated factor (LCSF) [5]. According to $[6,20,28,37,44,50,52-54,57,59,61,62$, $65,66,69,71,77,182,183,186,188-190,192]$, fatty acids composition (FAC) of SCGOME is mainly dominated by linoleic and palmitic acids followed by oleic, stearic and arachidic acids. This FAC structure yields a biodiesel with high cetane number $(\mathrm{CN})$ and oxidation stability (OS), lower iodine value (IV), acceptable higher heating value (HHV) and flash point (FP) besides higher cloud point (CP), pour point (PP), cold filter plugging point (CFPP) and kinematic viscosity (KV) higher than $5 \mathrm{~mm}^{2} / \mathrm{s}$ at $40{ }^{\circ} \mathrm{C}$. Linoleic acid has excellent emollient properties that can be utilized as a component for the prolongation of skin barrier while palmitic acid can protect skin from ultraviolet ray affection [130]. Tables 4-6 show a comparison of SCGO properties, FAC and SCGOME properties collected from various resources. The properties of SCGOME and its blends with Euro diesel (D100) and butanol 
have been reported in [5], SCGOME and its blends with butanol, pentanol, hexanol and Euro diesel (D100) have been reported in [81] while the properties of SCGOME and its blends with diesel (B5 and B20) has been reported in [62].

Oil content and some fuel properties of SCGOME from 8 different geographical locations including; Costa Rica, Honduras, Ethiopia, Indonesia, Kenya, Columbia, Brazil, and Vietnam has been reported by [20]. Analyses of all samples indicated that SCG contains in average 7$14 \%$ lipids. FAC of all samples contains high percentages of linolenic acid (44-50\%), palmitic acid (35-40\%) with low percentages of stearic (7-8\%) and oleic (7-8\%) acids. Analyses of fuel properties of SCGOME indicated that $\mathrm{KV}$ ranges between $3.5-5.5 \mathrm{~mm}^{2} / \mathrm{s}$, density between $841-927 \mathrm{~kg} / \mathrm{m}^{3}$ and PP between -1 to $16{ }^{\circ} \mathrm{C}$. SCGOME has been reported to have similar KV, HHV and flash point but higher density compared to Calophyllum inophyllum methyl ester (CIME) (Table 6) [193].

From literature, SCGOME can be produced by four main pathways:

1- Direct transesterification with catalytic alkaline-based transesterification or acidcatalyzed esterification $[6,20,28,53,56,60,64,65,70,82,182]$, methanol/carbon dioxide mixtures [68] and enzymatic catalysis/biocatalyst such as Candida rugose, Porcine pancreas, Pseudomonas fluorescens, Candida Antarctica lipase-B Mucor miehei, Pseudomonas cepacia, Rhizopus delemar, Thermomyces lanuginosus, Geotrichum candidum and Candida rugosa $[48,60,71,80,194]$.

2- Catalytic reaction of two steps of acid-catalyzed esterification followed by alkalinebased transesterification $[5,21,50,52,59,62,64,66,78]$.

3- Non-catalytic transesterification [53].

4- In-situ transesterification $[54,57,61,69,72-74,77]$.

\subsection{1}

Insight into in-situ transesterification as a promising biodiesel production method from SCG

Liu et al., [54] proposed an alternative pathway to obtain SCGOME directly from SCG (insitu) without the need for the solvent extraction process. Before that, the oil content of SCG was determined to be $17.32+0.93$ wt. $\%$. The process was conducted in a Soxhlet apparatus in which SCG were impregnated with $\mathrm{H}_{2} \mathrm{SO}_{4}$ at various concentrations (5-20\% of dry SCGs weight) for esterification process since the AV of SCGO was in the range 6.18-6.94 mg KOH/ g oil. The optimum reaction condition was $70{ }^{\circ} \mathrm{C}$ and $12 \mathrm{~h}$ with 20 wt. $\% \mathrm{H}_{2} \mathrm{SO}_{4}$. This was 
followed by adding deionized water and heating the slurry at $70{ }^{\circ} \mathrm{C}$ with stirring for $3 \mathrm{~h}$ and then dried in an oven for $24 \mathrm{~h}$ at $105^{\circ} \mathrm{C}$. The dried impregnated SCGs were load in cellulosic thimble where methanol was placed in the distillation flask to perform the transesterification process. The results of the FAC of SCGOME showed that it has 44.3\% palmitic acid (C16:0) followed by $30.8 \%$ linoleic acid (C18:2), 9.7\% stearic acid (C18:0), 6.1\% oleic acid (C18:1), $3.3 \%$ arachidic acid (C20:0) and small fractions of linolenic acid (C18:3) and behenic acid (C22:0) of 0.8 and $0.3 \%$ respectively. Biodiesel yield was $17.08 \pm 0.70 \mathrm{wt} . \%$ based on SCG. This was equivalent to oil to biodiesel conversion of $98.61 \mathrm{wt} . \%$. Under the optimal reaction condition of $12 \mathrm{~h}$, the KV of biodiesel was $5.36 \mathrm{~mm}^{2} / \mathrm{s}$ with OS of $6.62 \mathrm{~h}$ which met ASTM D6751 standards. However, AV of biodiesel was $0.8 \mathrm{mg} \mathrm{KOH} / \mathrm{g}$ which failed to satisfy ASTM D6751 standards. Thus, SCGOME was washed with $1 \% \mathrm{NaOH}$, and the AV of the final product was reduced to $0.31 \mathrm{mg} \mathrm{KOH} / \mathrm{g}$ to meet ASTM D6751 standards of maximum $0.5 \mathrm{mg} \mathrm{KOH} / \mathrm{g}$.

Park et al., [57] conducted in-situ transesterification in which $0.6 \mathrm{~g}$ of SCG was mixed with methanol, chloroform as a solvent and $\mathrm{H}_{2} \mathrm{SO}_{4}$. Different reaction parameters to optimize the production of SCGOME were set as follow, methanol $(0.25-3 \mathrm{ml})$, chloroform $(0-2 \mathrm{ml})$ and $\mathrm{H}_{2} \mathrm{SO}_{4}(0-0.3 \mathrm{ml})$. The effect of moist content was also studied besides some other acid catalysts such as nitric acid, $\mathrm{HCl}$ and acetic acid. It has been found the maximum FAME yield was over 16.75 wt.\% at $95{ }^{\circ} \mathrm{C} . \mathrm{H}_{2} \mathrm{SO}_{4}$ and $\mathrm{HCl}$ were found the best catalysts. FAC of SCGOME was dominated by linoleic acid (C18:2) (41.88\%) and palmitic acid (C16:0) (35.4\%) followed by oleic acid (C18:1) (9.22\%) and stearic acid (C18:0) (6.72\%) respectively.

Tuntiwiwattanapun et al., [61] studied in-situ transesterification process for SCG into SCGOME. After sun drying, five different sizes of SCG were fractionated using US sieve sizes No. $12(1.68 \mathrm{~mm}), 16(1.19 \mathrm{~mm}), 18(1.00 \mathrm{~mm}), 40(0.42 \mathrm{~mm})$ and $60(0.25 \mathrm{~mm})$. AV was calculated as $5.93 \pm 0.02 \mathrm{mg} \mathrm{KOH} / \mathrm{g}$ oil, and oil content was $18.8 \pm 0.5$. To reduce the $\mathrm{AV}$, $36 \mathrm{~g}$ of each SCG fraction was deacidified by washing with $120 \mathrm{ml}$ methanol and mixed at $15.7 \mathrm{rad} / \mathrm{s}$ for $1 \mathrm{~h}$ at $45^{\circ} \mathrm{C}$. The slurry was filtered and rinsed with $15 \mathrm{ml}$ methanol followed by drying in an oven at $75{ }^{\circ} \mathrm{C}$ overnight. Afterwards, a solution containing $2.225 \mathrm{NaOH}$ was dissolved in $250 \mathrm{ml}$ methanol followed by suspending $30 \mathrm{~g}$ of deacidified SCG in $105 \mathrm{ml}$ methanol in the reactor while mixing at $15.7 \mathrm{rad} / \mathrm{s}$ for $3 \mathrm{~h}$ at a temperature between 30 and $60^{\circ} \mathrm{C}$. A calculated amount of $\mathrm{H}_{2} \mathrm{SO}_{4}$ then neutralized the catalyst. The slurry was then filtered and rinsed with methanol. Methanol was then removed by rotary evaporator. The 
product was then transferred to a separation funnel in which n-hexane was added to separate SCGOME from glycerol. The mixture of SCGOME-hexane was then washed 2 times with deionized water. The product was finally incubated for $2 \mathrm{~h}$ in a water bath at $50{ }^{\circ} \mathrm{C}$ to remove hexane. Finally, SCGOME was incubated in an oven at $105^{\circ} \mathrm{C}$ for 1 hour to remove moisture. FAC was mainly comprised of $42 \%$ linoleic acid (C18:2), 34\% palmitic acid (C16:0), $11 \%$ oleic acid (C18:1), 7\%stearic acid (C18:0), 3\% arachidonic acid (C20:4) and 3\% other fatty acids. The KV of SCGOME was $4.18 \pm 0.03 \mathrm{~mm}^{2} / \mathrm{s}$ which satisfies ASTM D 6751 standards. However, AV $(1.4 \pm 0.18 \mathrm{mg} \mathrm{KOH} / \mathrm{g})$ did not satisfy ASTM D6751 standards of maximum $0.5 \mathrm{mg} \mathrm{KOH} / \mathrm{g}$. In another study, Tuntiwiwattanapun et al., [77] proposed an optimized methanol washing pretreatment process of SCG $\left(3.7 \mathrm{ml}\right.$ methanol $\left./ 1 \mathrm{~g} \mathrm{SCG}, 30{ }^{\circ} \mathrm{C}, 1 \mathrm{~h}\right)$ that successfully reduce its acid value from $10.28 \mathrm{mg} \mathrm{KOH} / \mathrm{g}$ oil to $0.78 \mathrm{mg} \mathrm{KOH} / \mathrm{g}$ oil. This was followed by in-situ transesterification of SCG. Optimized parameters of $2.5 \mathrm{~g}$ of $\mathrm{KOH}$ in 100 $\mathrm{cm}^{3}$ methanol with $25 \%$ isopropanol (by volume) to $1 \mathrm{~g}$ of SCG at $30{ }^{\circ} \mathrm{C}$ for $1 \mathrm{~h}$ achieved a biodiesel yield of $10.2 \%$ SCGOME/SCG. FAC of the extracted oil was mainly comprised of 45\% linoleic acid (C18:2), 35\% palmitic acid (C16:0), 9\% oleic acid (C18:1), 6\% stearic acid (C18:0), 3\% arachidonic acid (C20:4)

Son et al., [72] applied in-situ transesterification process for wet SCG with supercritical methanol. Optimized biodiesel yield of $10.17 \mathrm{wt} \%$ of dry SCG mass was obtained at reaction conditions of $270{ }^{\circ} \mathrm{C}, 90$ bars, space loading $58.4 \mathrm{ml} / \mathrm{g}$, methanol to wet SCG ratio 5:1and reaction time20 min. Park et al., [73] attempt to investigate the solvothermal effect of 1,2dichloroethane (DCE) for in-situ transesterification of SCG with ethanol over $160{ }^{\circ} \mathrm{C}$. An optimized yield of biodiesel (fatty acid ethyl ester) of $11.8 \mathrm{wt} \%$ (mass of dried SCG) was obtained with $3.36 \mathrm{ml}$ ethanol and $3.16 \mathrm{ml}$ DCE at $196.8^{\circ} \mathrm{C}$. In both studies, authors indicated that this process eliminates the need for the drying process, extraction process and acid catalyst providing not only economic feasibility but also the environmental advantage of recycling waste.

Calixto et al., [68] indicated that $89.4 \%$ of SCOME yield is obtained when using supercritical methanol in-situ transesterification process of SCG (473-603 K, 10-30 MPa). Carbon dioxide $\left(\mathrm{CO}_{2}\right)$ was then added to methanol to reduce the temperature and pressure. It has been found that at a reaction temperature of $573 \mathrm{~K}$, the pressure of $10.0 \mathrm{MPa}$ and a $\mathrm{CO}_{2} / \mathrm{MeOH}$ molar ratio of 0.11 yielded $93.4 \%$ of SCGOME. 


\subsection{Fuel pellet}

Several studies examined and highlighted the potential of SCG as fuel pellets $[\mathbf{5 - 7 , 5 1 , ~ 6 5 , ~ 6 6 , ~}$ 79, 83-89]. Table 7 conducts a comparison between the calorific values of SCG, DSCG and other biomass residues $[5,14,51,52,62,65,70,80,83,84,88-90,181,192]$. The results of SCG range between (19.3-24.913 MJ/kg) while for DSCG range between (19-21.54 MJ/kg). The heat of combustion of SCG (kg/kg dry) at different degrees of humidity (w.b.) has been reported and compared with different biomass in [84]. Authors indicated that, SCG compared to other biomass is considered as an excellent fuel as it has a higher heat of combustion indicating that coffee industry could become self-sufficient in thermal energy with some technological advancements and investment to improve the performance of boilers. Energy, emissions and combustion characteristics of agro-pellets from pure SCG and SCG mixed with pine sawdust in a residential pellet boiler has been investigated by [87]. It was found that the use of pure SCG lowered boiler efficiency along with an increase in particle and gas emissions. However, when SCG was mixed with pine sawdust (50/50 wt.\%), combustion parameters (emissions and boiler efficiency) were very close to wood pellets and satisfied the NF agro-pellets standard (French standards) which are essential to selling before commercializing it. The same conclusion was confirmed by Jeguirim et al., [86].

Addition of $10 \%$ and $25 \%$ of SCG to beech wood increased its calorific values from 18.77 $\mathrm{MJ} / \mathrm{kg}$ to $19.12 \mathrm{MJ} / \mathrm{kg}$ and $20.32 \mathrm{MJ} / \mathrm{kg}$ respectively [88]. The effect of mixing DSCG with glycerin (content from 20-40\%) has been reported in [66] in which glycerin was obtained as a by-product of biodiesel production from SCGO. It has been found that mixing DSCG with $40 \%$ glycerin yield a heating value of $21.6 \mathrm{MJ} / \mathrm{kg}$ compared to $19.3 \mathrm{MJ} / \mathrm{kg}$ ( $20 \%$ glycerin). Similar work has been reported by Potip and Wongwuttanasatian [89] who examined the effect of mixing SCG with crude glycerol at different ratios of 100:0, 95:5 and 90:10 and different theoretical air supply of 550\%,700\%, 850\%, and $1000 \%$. Both parameters have been found to affect the combustion of SCG briquettes. The combustion equation of $100 \%$ theoretical air for 100g SCG and 1-mole crude glycerol can be written as follow:

$$
\begin{aligned}
& \left(4.551 \mathrm{C}+3.295 \mathrm{H}_{2}+1.088 \mathrm{O}_{2}+0.142 \mathrm{~N}_{2}\right)+5.111\left(\mathrm{O}_{2}+3.76 \mathrm{~N}_{2}\right)+\mathrm{Ash} \rightarrow 4.551 \mathrm{CO}_{2}+ \\
& 3.295 \mathrm{H}_{2} \mathrm{O}+19.359 \mathrm{~N}_{2}+\text { Ash } \\
& \mathrm{C}_{3} \mathrm{H}_{8} \mathrm{O}_{3}+3.5\left(\mathrm{O}_{2}+3.76 \mathrm{~N}_{2}\right) \rightarrow 3 \mathrm{CO}_{2}+4 \mathrm{H}_{2} \mathrm{O}+13.16 \mathrm{~N}_{2}
\end{aligned}
$$


Increasing the percentage of glycerol in the briquettes from 5-10\% increased the heating value to 21.21 and $21.55 \mathrm{MJ} / \mathrm{kg}$ respectively compared to $21.14 \mathrm{MJ} / \mathrm{kg}$ of SCG with increasing the burning rate up to $53.8 \%$ and $10 \%$ higher combustion temperatures. Results showed that the briquette ratio of $90(\mathrm{SCG}): 10$ (glycerol) and $850 \%$ theoretical air gave the maximum temperature and combustion rate of $533.4{ }^{\circ} \mathrm{C}$ and $0.20 \mathrm{~g} / \mathrm{s}$ respectively. Compositions of the exhaust gases, namely carbon monoxide, nitrogen dioxide, sulfur dioxide) and acrolein gas were all satisfying the international standards.

\subsection{Bio-oil}

Pyrolysis is a physicochemical process of thermal decomposition of organic substances, occurring under inert atmosphere (Nitrogen), limited oxygen and high temperatures between 500-1000 ${ }^{\circ} \mathrm{C}$. Pyrolysis degradation yields liquid (bio-oil and water phase), biochar and syngas $[91,96,99]$. These proportions depend on pyrolysis technique and reaction parameters (slow or fast pyrolysis) [99]. Bio-oil can be utilized as fuel or chemical [96] while bio-char can be used as an energy source, adsorbent, soil amendment or land applied for carbon sequestration [94]. Several studies examined the pyrolysis potential of both SCG and DSCG as a source for bio-oil and biochar $[62,90,92-96,98-100]$ while the co-pyrolysis (coliquefaction) of SCG with polypropylene (plastic) has been reported in [91] and paper filter, corn stalk, and white pine have been reported in [97]. Co-pyrolysis causes improvement in both oil yield and crude oil quality. Improvement in $\mathrm{KV}$ and molecular weight was obtained following this concept. The optimum conditions were the temperature of $250{ }^{\circ} \mathrm{C}$ and a mixing ratio of $1: 1$.

The effects of different operating parameters such as retention times (5 min, $10 \mathrm{~min}, 15 \mathrm{~min}$, $20 \mathrm{~min}$ and $25 \mathrm{~min})$, reaction temperatures $\left(200,225,250,275\right.$ and $\left.300{ }^{\circ} \mathrm{C}\right)$, water/feedstock mass ratios $(5: 1,10: 1,15: 1$ and 20:1) and initial pressure of process gas (2.0 MPa and 0.5 $\mathrm{MPa}$ ) on bio-oil yield from SCG via hydrothermal liquefaction (HTL) in a stainless-steel autoclave reactor under Nitrogen was investigated by [90]. The highest bio-oil yield of $47.28 \%$ (mass fraction) was obtained at optimized conditions of $275^{\circ} \mathrm{C}, 10 \mathrm{~min}$ retention time and water/feedstock mass ratio of 20:1 with an initial pressure of 2.0 MPa.

The effect of temperature on bio-oil yield has been studied by [93]. The highest yield of biooil was obtained $823 \mathrm{~K}$ (54.85 wt.\%) compared to 36.75 wt. $\%$ at $673 \mathrm{~K}$ and then decreased at $873 \mathrm{~K}$. In contrast to that, the highest bio-oil yield of $61.8 \%$ of was obtained at $773 \mathrm{~K}$ [94]. Similar to [99] who achieved a maximum bio-oil yield of 56.09 \pm 0.22 (wt.\%), 21.98 (wt.\%) 
syngas and 21.93 $\pm 0.19 \%$ (wt.\%) bio-char through fast pyrolysis of SCG, [96] who achieved a maximum bio-oil yield of $30.51 \%$ (mass fraction) at the same temperature (773 K), $66 \mathrm{wt} \%$ at around $627^{\circ} \mathrm{C}(900 \mathrm{~K})$ [95] and $36 \mathrm{wt} \%$ at $813 \mathrm{~K}$ [100].

A detailed comparison of HHV and elemental composition (ultimate analysis) of SCG, DSCG and bio-oils derived from SCG and DSCG and other biomass are shown in Table $8[\mathbf{5 , 4 2 , 5 0 ,}$ $51,62,65,70,86-88,90,92-95,97,100,105,106,110,111]$.

From Table 8, it can be seen that conversion of both SCG and DSCG to bio-oil seems to be more practical compared to many other woody biomass which have lower energy content (19$21 \mathrm{MJ} / \mathrm{kg}$ ). It can be also concluded that bio-oil from SCG has higher HHV than DSCG due to lower carbon and hydrogen contents and higher oxygen content in bio-oil from DSCG caused by lipids extraction [62]. Moreover, combustion of bio-oil from DSCG may cause higher $\mathrm{NO}_{\mathrm{x}}$ emissions as it has relatively higher Nitrogen content than SCG.

\subsection{Bioethanol}

The potential of producing bioethanol from SCG has been highlighted in $[\mathbf{5 3}, \mathbf{5 9}, \mathbf{7 9}, \mathbf{1 0 1}$, 102]. Nevertheless, direct conversion of SCG to bioethanol (without oil extraction) has been reported to be not feasible due to the existence of triglyceride and FFA which inhibits the activity of enzymatic saccharification process [53]. This indicates that lipid extraction from the SCG is vital to produce bioethanol where lipids can be utilized to produce biodiesel. Such strategy would set the initial stage of bio-refinery from SCG industry as SCGO can be reacted with bioethanol to produce FAEE $[\mathbf{5 3}, \mathbf{5 9}]$. Another practical pathway for SCG bio-refinery in which phenolic extraction with ethanol was applied to obtain chlorogenic acid prior to produce bioethanol was proposed by [101]. This pathway increased the percentage of sugars in the solids and the sugar release efficiency. This is because of the extraction of phenolic enhanced the breakdown of polymers with no loss of soluble sugars. The yield of bioethanol from DSCG has been reported to be $0.43 \mathrm{~g} / \mathrm{g}$ [53] and $0.50 \mathrm{~g} / \mathrm{g}$ [59] compared to $39 \mathrm{~g} / \mathrm{L}$ phenolic extracted and $22 \mathrm{~g} / \mathrm{L}$ non-extracted phenolic SCG [101].

\subsection{Biogas}

The potential of producing biogas from SCG through anaerobic digestion and co-digestion has been recently investigated in [103-111]. SCG is a valuable material for fermentation process due to its excellent elemental composition and $\mathrm{C} / \mathrm{N}$ ratio (Table 8), chemical composition, and existence of polysaccharides, proteins, and minerals [104]. Table 9 shows 
the composition of SCG collected from literature $[1,7,80,97,103,104,106,108-111,127$, 163, 195]. Mineral composition of SCG has been reported in [103, 163]. Composition varies from one study to another. This is attributed to the different varieties of coffee used in production [84]. Anaerobic digestion of coffee waste $(\mathrm{CW})[\mathbf{1 9 6}, \mathbf{1 9 7}]$ and generated coffee wastewater [35, 36, 198] has also been described earlier. Anaerobic digestion of SCG under mesophilic conditions have been reported in $[104,111]$ while thermophilic conditions have been reported in $[\mathbf{1 0 6}, \mathbf{1 1 0}]$. Biogas yields has been reported to range from $0.500-0.598 \mathrm{~m}^{3} / \mathrm{kg}$ dry organic matter with methane concentration 55-61\% [104], in agreement with [107] $(0.54$ $\mathrm{m}^{3} / \mathrm{kg}$ ). The methane production ranged from $0.271-0.325 \mathrm{~m}^{3} / \mathrm{kg}$ dry organic matter [104], in agreement with [197] $\left(0.25-0.28 \mathrm{~m}^{3} / \mathrm{kg}\right)$, [196] $\left(0.24-0.28 \mathrm{~m}^{3} \mathrm{Ch}_{4} / \mathrm{kg} \mathrm{VS}_{\text {initial }}\right)$, [105] 296 ml.CH $4 / g-V S$, and $[111,197]\left(0.36 \mathrm{~m}^{3} \mathrm{CH}_{4} / \mathrm{kg} \mathrm{VS}\right)$.

According to Lus et al., [105], anaerobic co-digestion of SCG with cow manure achieved a $48 \%$ increase in biogas yield with $53.7 \%$ methane $\left(\mathrm{CH}_{4}\right)$ and $37.8 \% \mathrm{CO}_{2}$ yield. The output of

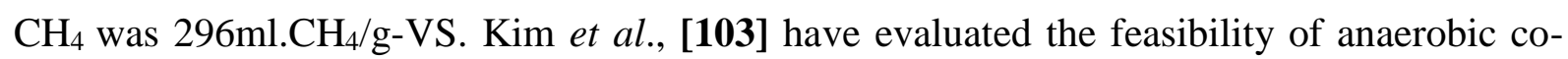
digestion of SCG with various organic wastes, i.e., FW, Ulva biomass, waste activated sludge, and whey. Co-digestion of SCG with the other co-substrates showed similar or higher methane production than pure SCG. Among all substrates, the highest cumulative methane production of $0.355 \pm 0.09 \mathrm{~L} \mathrm{CH}_{4} / \mathrm{g} \mathrm{VS}$ in was reported for FW75SCG25 which was $13.1 \%$ higher than pure SCG. Similar improvement pattern was reported by authors when codigesting SCG with Ulva biomass (2.5\% COD basis) achieving 51.8\% of $\mathrm{CH}_{4}$ [109].

\subsection{Hydrocarbon fuels}

Most of the published work on SCGO indicated that single alkaline-catalyzed transesterification reaction is impossible to directly convert it to biodiesel due to its high AV value besides the high saturation level in SCGO yields biodiesel with high CP, PP, and CFPP which causes many problems in fuel tank especially in cold regions. Therefore, production of hydrocarbon fuels from SCGO has been suggested in $[112,113]$ as another option to produce biofuels from SCGO. It has been reported that in every $1 \mathrm{~kg} \mathrm{SCG}, 77 \mathrm{~g}$ of hydrocarbons is produced allowing a driving distance of $\sim 2.4 \mathrm{~km}$ (AudiA31. 6TDIULTRA, $\sim 3.2 \mathrm{~L} / 100 \mathrm{~km}$ ) [112].

Hydrotreating process of SCGO to produce hydrotreated diesel fraction (HDF) using catalysts such as $\mathrm{NiMo} / \gamma-\mathrm{Al}_{2} \mathrm{O}_{3}$ and $\mathrm{Pd} / \mathrm{C}$ has been reported by [113] while polymethylhydrosiloxane (PMHS) has been reported by [112]. Table 10 shows a comparison of HDF and commercial 
bio-hydrogenated diesel (BHD) properties. It can be seen that he HDF catalyzed by NiMo/ $\gamma$ $\mathrm{Al}_{2} \mathrm{O}_{3}$ exhibits lower density and $\mathrm{KV}$ and higher cetane index compared to HDF catalyzed by $\mathrm{Pd} / \mathrm{C}$. These results support that $\mathrm{NiMo} / \gamma-\mathrm{Al}_{2} \mathrm{O}_{3}$ has higher catalytic activity over $\mathrm{Pd} / \mathrm{C}$. These results also show that BHD has lower density and kinematic viscosity than SCGOME.

\subsection{Valorization of SCG into value-added products}

SCG contains large amounts of organic compounds (more than 1000 individual compounds) such as proteins, carbohydrates, tannins, fibers, cellulose, non-protein nitrogenous, fatty acids, amino acids, polyphenols, minerals lignin and polysaccharides $[8,38,41,43,44,63,80,124]$ namely; galactomannans and arabinogalactans [43, 45-47] besides more than 700 volatile compounds that remain insoluble in SCG and thus can be toxic to the environment. SCG retain approximately $70 \%$ of the polysaccharides present in the roasted coffee beans [124]. SCG contains various bioactive compounds such as polyphenols, flavonoids, sugars, proteins, and Millard reaction products. It has been reported to contain a considerable amount of protein (8.97-17.44\%), carbohydrates (78.5\%), ash (1.3-2.77\%), tannins (30.36\%), nitrogen content (2.03-3.97\%) and cellulose (8.6-24.3\%) (Tables 8 \& 9) making it a promising material for bioactive compounds and compost besides its huge potential as adsorbent and nanocomposite. These compounds can be used as antioxidants and antimicrobial agents in food, cosmetics and pharmaceutical industries [38, 124]. Polysaccharides; galactomannans and arabinogalactans are polymers that can be used as dietary fibre and present immunestimulatory activity [43]. This is also a useful resource for the food industry [40]. Moreover, SCG has a high potential as an adsorbent with environmental and economic benefits [160]. SCG and DSCG are ideal compost for the soil since they C/N ratio higher than 20:1 [52]. DSCG have vital applications in cosmetic products due to its high levels of linoleic acid and palmitic acid [29]. SCG, SCGO and DSCG have been found to be excellent substrate for polyhydroxyalkanoates (PHAs) production due to the higher number of carbon atoms per weight. This indicates the high potential of coffee industry to produce biopolymers [175-178] and thus eliminates the need of using edible oil plants. However, it was concluded that additional work is required to increase biopolymers yield (for instance only $8 \mathrm{wt} \%$ of residue per total mass of polyol obtained from SCG) [178]. A summary of SCG recycling potential to produce value-added products is highlighted in Table 11. 


\subsection{Membrane technology for SCG-integrated biorefinery}

Membrane technology has the potential to play an anchor role in process intensification, biofuels or other value-added products separation and purification in the SCG-integrated biorefinery production process. Among the different separation techniques, membrane technology facilitates a highly selective separation and fractionation capabilities, reduced chemical consumption and labour costs, fewer requirements of floor space, wide flexibility in operation and energy saving separation [199, 200]. Membrane technology is associated to various processes of SCG-integrated biorefinery such as separation and purification of distinct molecules, removal and/or recovery of process inhibitors and enzymes from hydrolysis, biogas upgrading; and production of bioethanol, biodiesel, bio-oil, hydrocarbon fuels, hydrogen and bioethanol dehydration. The membrane is an ultra-thin semipermeable barrier which is placed between two fluids to separate them by permitting transport of one or more components from one fluid to other. It is a mass transfer unit operation employed for separation of gas and liquid streams in an SCG-integrated biorefinery. Membranes utilized in bioseparation are semi-permeable and porous in nature to separate a variety of process streams and composed of organic polymers, ceramics, metals as well as gas and liquid membranes. In recent years, inorganic and hybrid membranes are commonly used. The fluid that passes through the membrane is called permeate and the fluid which is left behind is called retentate [201, 202]. A variety of specific membrane processes are of particular interest for SCG-integrated biorefinery such as microfiltration (MF), nanofiltration (NF), ultrafiltration (UF), membrane distillation (MD), vacuum filtration, pervaporation (PV), diafiltration (DF), dialysis and hyperfiltration (reverse osmosis). PV membrane is non-porous and separation driving force is a chemical potential gradient, whereas MD is equipped with porous hydrophobic membrane driven by a thermal gradient. On the other hand, membranes of UF, MF and NF processes are also porous, but the driving force is hydrostatic pressure. The flat sheet/plate and frame, hollow fibre and spiral-wound modules are the commonly used configurations [203]. The characteristics and applications of various membrane processes for SCG-integrated biorefinery are presented in Table 12.

In SCG-integrated biorefinery, membranes would be employed in upstream and downstream separation and purification to concentrate and recover the biofuels and value-added products. Pervaporation, hyperfiltration and gas/ vapour permeation have been suggested for producing bioethanol. Hyperfiltration membranes are required which can primary reject water in the presence of bioethanol. Mehta [204] firstly conducted a preliminary evaluation of bioethanol 
dehydration by employing a hypothetical hyperfiltration membrane. After that, Leeper and Tsao [205] adapted two ways of hyperfiltration for recovery and purification of bioethanol, which resulted in a significant reduction in energy demand for bioethanol recovery. Vapour permeation is a membrane process in which components pass through the membrane entirely in the vapour phase. Pervaporation is a new development in membrane separations, which includes phase change and potential for bioethanol production. Since, it does not depend on vapour-liquid equilibrium, azeotropes and close boiling liquid can be separated efficiently. LURGI pervaporator integrated with a special plate type membranes and permeate condenser has been proposed for effective bioethanol recovery in biorefinery concept at commercial scale. About three decades earlier, Sander and Soukup [206] presented the operation and design of pervaporation plant for bioethanol dehydration, which revealed the potential of membrane technology for biofuel separation and purification.

Bio-oil produced is contaminated with finer particles $(<10 \mu \mathrm{m})$, leading to problems with enduse, storage and necessitating further treatment. Conventional techniques such as cyclone filtration and hot gas filtration only remove the larger particles $(>10 \mu \mathrm{m})$ [207]. Javaid et al., [208] applied microfiltration to explore the feasibility of removing finer particles. The results demonstrated that microfiltration decreased the overall finer ash contents in bio-oil significantly. Moreover, the concentration of critical constituents associated with bio-oils energy content was not affected by microfiltration process. Similarly, biodiesel also contains some intermediates and residual compounds produced in the reaction in addition to the main product of fatty acid alkyl esters (FAAE) and byproduct glycerol. These contaminants will negatively influence both environment and engine at end-user [209]. Currently, membrane separation is new to biodiesel production but recent studies have revealed the promising potential for enhanced efficiency. Membranes can be installed in either membrane reactor for transesterification or as a final separation and purification to refine biodiesel. Membrane reactors combined the reaction and membrane filtration into a single process, leading to enhanced conversion for equilibrium limited reactions by taking out reaction products from the reactor through membranes. The glycerol from the crude biodiesel and enzymatic reaction was removed using membrane extraction, while membrane separation processes are employed to remove glycerol during biodiesel refinement [210]. Mostly, inorganic membrane reactors were used and high oil to FAME conversion was observed. Baroutian et al., [211] compared the chemical and physical properties of biodiesel produced by membrane reactors with standard specifications. The produced biodiesel was of high efficiency and fulfil ASTM 
standard limits of all the properties. However, performance and economic aspects of largescale membrane systems have not been examined for the treatment of bio-oil and biodiesel at industrial scale.

Biohydrogen and biogas produced in SCG-integrated biorefinery also required upgrading and enhancement to utilize as a substitute for natural gas or its exploration as a transport fuel. Apart from methane, other gases (such as $\mathrm{CO}_{2}, \mathrm{H}_{2} \mathrm{~S}$ or $\mathrm{N}_{2}$ ) in biogas are not required and are pondered as biogas pollutants because higher contents of these gases lower the lower calorific value (CLV) in biogas. Presently, different chemical/physical/biological technologies are available at a commercial level to separate/transform to upgrade biogas and biohydrogen, including adsorption, absorption and membrane separation [212]. However, conventional technologies are cost-intensive. In contrast, membrane technology is a promising costeffective technique for biogas and biohydrogen upgrading and enhancement [213]. The selective permeability characteristics of membranes permit the separation of the biogas and hydrogen components. The rate of permeation depends on the sorption coefficient of gases and the membrane materials, affecting the selectivity [214]. Presently, four main manufacturing configurations exist for gas-gas membrane cascades including single-stage, two-stage with a recirculation circle, two stage with a stream of biogas sweeping and three stage with sweep biogas stream [215, 216]. In SCG-integrated biorefinery, the role of produced biogas and hydrogen in the energy system creates an environmental and economic incentive for graduation and enhancement.

One of the key challenges in the use of membrane technology for SCG-integrated biorefinery is membrane fouling. The solidify solutes/contaminants accumulate on the membrane surface and/or within the pore matrix, as a result, increase the filtration resistance and decrease the membrane performance [217]. Membrane fouling mechanism varied depending on the process such as the cake layer and gel layer formation, pore-clogging/plugging and adsorption/desorption [218]. This would lead to frequent cleaning and/or subsequent membrane replacement, resulting in higher operating and capital costs. Most of the studies focused on the process efficiency and limited attention paid to address the membrane fouling problems, wherever membrane technology is applied for bioenergy production and biorefinery [201]. Membrane fouling would be organic, inorganic, reversible/irreversible, microorganism fouling during the separation and purification of bioethanol, bio-oil, biodiesel, glycerol, biogas, biohydrogen, enzymes and inhibitors depending on the compositions of feed and system characteristics. Recently, energy efficient fouling mitigation strategies have been 
developed including new membrane material developments; control the properties of the bulk fluid in the system, optimization of operating conditions, addition biocarriers, chemical enhanced backwash and different biological ways to reduce fouling in an effective way [219, 220].

\subsection{Proposed SCG bio-refinery}

Characteristics of SCG are a determinant factor in deciding the bio-refinery design of SCG industry. In this review, several important characteristics such as elemental composition (SCG and DSCG), chemical compositions (SCG), calorific value (SCG and DSCG), oil content (SCG), fatty acid composition (SCGOME), physical and chemical properties (SCGO and SCGOME), etc. were presented. Moreover, several opportunities to produce biofuels and value-added products were presented in Sections 4 and 5. Some earlier studies have proposed some pathways to recycle SCG such as $[6,52,53,66,181]$. Based on the presented review, a complete SCG bio-refinery is presented in Fig. 6 (a). Based on the evaluation of about 233 published research work on SCG recycling, the best pathway of SCG recycling is to extract the oil to obtain SCGO and the remaining cake (DSCG). As can be seen in Fig. 6 (b) following this pathway allows to produce 7 different biofuels namely; bioethanol, bio-oil, biodiesel, hydrocarbon fuel, biogas, biohydrogen, and fuel pellets and 5 valuable added value products namely; bioactive compounds, adsorbents, compost, biochar, and glycerin. Therefore, 12 useful products can be obtained from SCG refineries. This opens the gates to protect the environment from harmful emissions caused by the organic compounds presented in SCG, create new jobs, produce biofuels and value-added products and alleviate the tax on landfills.

\subsection{Valorization of other coffee industry by-products}

Although coffee husks $(\mathrm{CH})$, peel and pulp comprise nearly $45 \%$ of the cherry are the main residue of coffee agro-industry $[8, \mathbf{1 7}]$, most of research done on coffee industry by-products focused on SCG while others valuable residual such as its exocarp (skin), mesocarp (mucilage), and endocarp (parchment), CS and pulp which are produced during the manufacturing process have been relatively rarely investigated [221].

Caffeine content, total polyphenol content and total antioxidant capacity of CS has been reported in $[3, \mathbf{1 3}, \mathbf{2 2}, \mathbf{2 2 2}, \mathbf{2 2 3}]$. The caffeine content in CS was $10 \pm 1.1 \mathrm{mg} / \mathrm{g}$ of CS, 3.5 times lower than most coffee brews, Total polyphenol content and total antioxidant capacity 
of CS was equal to16.1 $\pm 1.2 \mathrm{mg} / \mathrm{g}$ of CS and $138.8 \pm 14.8 \mathrm{mmol}$ of reduced iron per $\mathrm{kg}$ of CS respectively. This is similar to other sources of food antioxidants such as dark chocolate, herbs, and spices. Therefore, CS can be used as an excellent food supplement as it can increase the total antioxidant capacity of various food products. Moreover, it can serve as a good source for phenolic compounds (chlorogenic acids) that can be used as a useful medicine against several chronic diseases. Similarly, $\mathrm{CH}$, skin, and pulp can be a source of phytochemicals for the food and pharmaceutical industries since four major classes of polyphenols (viz., flavan-3-ols, hydroxycinnamic acids, flavonols, and anthocyanidins) exist. Moreover, they are rich in carbohydrates (35\%), proteins (5.2\%), fibers (30.8\%) and minerals (10.7\%) [17]. The production of low-cost adsorbents from $\mathrm{CH}$ has been reported by [224]. The potential of coffee pulp and $\mathrm{CH}$ to produce enzymes, aroma compounds, mushrooms, compost and vermicomposting have been reported by [225]. Authors also indicated the potential of $\mathrm{CH}$ hydrolysate to be used as a substrate for bioprocesses. Valorization of $\mathrm{CH}$ to produce biogas $[18,19]$, bioethanol, solid biofuels besides composting and vermicomposting [18] has also been reported. Bioethanol production from coffee mucilage [221, 226] and coffee pulp [227], coffee residue [228] using Saccharomyces cerevisiae as yeast has been reported. CS has been reported to be a valuable source of soluble dietary fibre $[\mathbf{3 , 2 2 2}$.

Biohydrogen production through co-digestion of coffee mucilage and swine manure at a $\mathrm{C} / \mathrm{N}$ ratio 53.4 and increase in organic load to improve hydrogen production has been reported by [229]. Biogas production from a mixture of coffee seed skin, seed refuse and coffee product refuse has been reported in [230], coffee pulp has been reported in [231], while improving biogas yield through co-digestion of coffee-pulp and cow-dung in mesophilic conditions has been reported in $[\mathbf{2 3 2}, \mathbf{2 3 3}]$.

\subsection{Concluding remarks and future perspectives}

In this review, the opportunities for recycling SCG into biofuels and value-added products were presented. Moreover, other wastes generated from this industry such as coffee husk, coffee pulp, and coffee silverskin have also been highlighted. SCG contains large amounts of organic compounds (more than 1000 individual compounds) such as proteins, carbohydrates, cellulose, non-protein nitrogenous, fatty acids, amino acids, polyphenols, minerals lignin and polysaccharides namely; galactomannans and arabinogalactans that remain insoluble and unextractable in SCG during the thermal water extraction process and thus can be valorized in different ways. Based on the evaluation of 233 published papers, SCG has been proven to be a 
potential feedstock to produce biodiesel, biogas, bioethanol, fuel pellets and bio-oil besides its promising potential to produce bioactive compounds, adsorbents, compost and polymers the milestone for bio-refineries from this industry as very promising environmental and feasible solution to save the environment, create jobs, produce biofuels and value-added products and offer many solutions to landfills. Coffee produces more oil per unit of land area than other traditional biodiesel crops with $386 \mathrm{~kg} / \mathrm{ha}$ compared to $375 / \mathrm{kg}$ ha for soybean. Oil content of SCG has been reported to range between $7-21.5 \%$ while acid value was reported to be extremely low $0.62 \mathrm{mg} \mathrm{KOH} / \mathrm{g}$ oil to extremely high $118.4 \mathrm{mg} \mathrm{KOH} / \mathrm{g}$ oil all of which depending on the storage duration, storage temperature, geographical location, type of coffee, moisture content, extraction process, and solvent used. Fatty acids composition of SCGOME is mainly dominated by linoleic and palmitic acids followed by oleic, stearic and arachidic acids. This structure yields biodiesel with high cetane number and oxidation stability, lower iodine value, acceptable higher heating value and flash point besides higher cloud point, pour point, cold filter plugging point, and kinematic viscosity higher than $5 \mathrm{~mm}^{2} / \mathrm{s}$ at $40{ }^{\circ} \mathrm{C}$. The results of the higher heating value of SCG range between (19.3-24.913 MJ/kg) while for DSCG range between (19-21.54 MJ/kg). These results are higher than other conventional biomass used as fuel pellets.

Moreover, glycerin which is produced as a by-product of the transesterification process can be mixed with DSCG to increase further its calorific value. The yield of bioethanol from DSCG has been reported to be $0.43-0.5(\mathrm{~g} / \mathrm{g})$. C/N of SCG has been reported to range between 16.9123.7, VS/TS between 96.5-99 and biogas yield from SCG has been reported to be 0.500-0.598 $\mathrm{m}^{3} / \mathrm{kg}$ while methane yield ranged from $0.25-0.325 \mathrm{~m}^{3} / \mathrm{kg}$. The higher heating value of biooils derived from SCG and DSCG was also found to be higher than other biomass. SCG has been also reported to contain considerable amount of protein (8.97-17.44\%), carbohydrates (78.5\%), ash (1.3-2.77\%), tannins (30.36\%), nitrogen content (2.03-3.97\%) and cellulose (8.6-24.3\%) making it a promising material for bioactive compounds and compost besides its huge potential as adsorbent and nanocomposite. Moreover, membrane processes in SCG-integrated biorefinery would show a great potential and present suitable performance criteria for biorefining and biofuels productions. Once implemented in an SCG-integrated biorefinery, membrane hybrid processes have the potential to further improve productivity by decreasing costs through the reduction of energy demands, processing steps and produce highquality final products. A refinery proposal has been suggested in this paper (Fig. 6).

Following this figure, authors suggest some future perspectives of SCG industry as follow: 
(1) Oil extraction from SCG is an important factor to improve the economics of SCG recycling industry as the direct use of SCG as fuel pellets seems not economical for the long run.

(2) Conversion of SCGO to biodiesel seems to be not economical due to the high acidity of SCGO. Therefore, pre-blending with lower acid value oils may seem to be one solution to cut down the cost of biodiesel production from SCG. In-situ transesterification process of SCG is another suggested approach. However, it has to be further inspected in the foreseen future.

(3) It appears that utilizing SCGO as an input raw material for producing value-added products such as polymers or in textile industry is an effective way to improve the economics of this industry rather than biofuel production.

(4) DSCG can be utilized in many different ways such as producing biofuels (biogas, bioethanol and fuel pellets) and value-added products. Producing bioethanol from DSCG followed by producing fatty acid ethyl ester (FAEE/biodiesel) by reacting bioethanol with SCGO may add to the economics of this industry. However, utilizing DSCG either to produce biogas or as raw material to produce adsorbents/active carbon material or bioactive compounds for food, pharmaceutical, cosmetic and chemical industries seems the most economical pathway so far.

(5) Some studies also recommended direct hydrolysis of SCG to firstly obtain sugar that is fermented to produce bioethanol followed by extracting the lipids from SCG and then further utilize the DSCG for other applications. 


\section{References}

1. Mussatto, S.I., Machado, E.M.S., Martins, S., Teixeira, J.A., Production, Composition, and Application of Coffee and Its Industrial Residues. Food and Bioprocess Technology, 2011. 4: p. 661-672.

2. Cruz, R., Cardoso, M.M., Fernandes, L., Oliveira, M., Mendes, E., Baptista, P., Morais, S., Casal, S., Espresso Coffee Residues: A Valuable Source of Unextracted Compounds. Journal of Agricultural and Food Chemistry, 2012. 60(32): p. 7777-7784.

3. Jiménez-Zamora, A., Pastoriza, S., Rufián-Henares, J., Revalorization of coffee byproducts. Prebiotic, antimicrobial and antioxidant properties. LWT - Food Science and Technology, 2015. 61(1): p. 12-18.

4. Cameron, A., O’Malley, S. Coffee Ground Recovery Program: Summary Report. 2016 [cited $20187^{\text {th }}$ August]; Available from: https://planetark.org/documents/doc-1397summary-report-of-feasibility-study-april-2016.pdf.

5. Atabani, A.E., Mercimek, S.M., Arvindnarayan, S., Shobana, S., Kumar, G., Cadir, M., Al-Muhtaseb, A.H., Valorization of spent coffee grounds recycling as a potential alternative fuel resource in Turkey: An experimental study. Journal of the Air \& Waste Management Association, 2017. 68(3): p. 196-214.

6. Kondamudi, N., Mohapatra, S.K., Misra, M., Spent coffee grounds as a versatile source of green energy. Journal of Agricultural and Food Chemistry, 2008. 56(24): p. 11757-11760.

7. Barbero, S., Fiore, E., The Flavours of Coffee Grounds: the coffee waste as accelerator of new local businesses. ANNALS of Faculty Engineering HunedoaraInternational Journal of Engineering, 2015. XIII(1): p. 57-63.

8. Campos-Vega, R., Loarca-Pina, G., Vergara-Castaneda, H.A., Oomahb, B.D., Spent coffee grounds: A review on current research and future prospects. Trends in Food Science \& Technology, 2015. 45(1): p. 24-36.

9. Kourmentza, C., Economo, Ch.N., Tsafrakidou, T., Kornaros, M., Spent coffee grounds make much more than waste: Exploring recent advances and future exploitation strategies for the valorization of an emerging food waste stream. Journal of Cleaner Production, 2018. 172: p. 980-992.

10. Maurin, O., Davis, A.P., Chester, M., Mvungi, E.F., Jaufeerally-Fakim, Y., Fay, M.F., Towards a Phylogeny for Coffea (Rubiaceae): Identifying Well-supported Lineages Based on Nuclear and Plastid DNA Sequences. Annals of Botany, 2007. 100(7): p. 1565-1583.

11. Barbin, D.F., Felicio, A.L.de Souza, M., Sun, D-W., Nixdorf, S.L., Hirooka, E.Y., Application of infrared spectral techniques on quality and compositional attributes of coffee: An overview. Food Research International, 2014. 61: p. 23-32.

12. Reis, N., Franca, A.S., Oliveira, L.S., Discrimination between roasted coffee, roasted corn and coffee husks by Diffuse Reflectance Infrared Fourier Transform Spectroscopy2013. LWT - Food Science and Technology, 2013. 50(2): p. 715-722. 
13. Bresciani, L., Calani, L., Bruni, R., Brighenti, F., Rio, D.D., Phenolic composition, caffeine content and antioxidant capacity of coffee silverskin. Food Research International, 2014. 61: p. 196-201.

14. Zuorro, A., Lavecchia, R., Polyphenols and energy recovery from spent coffee grounds. Chemical Engineering Transactions, 2011. 25: p. 285-290.

15. Rao, L.G.M., Ramalakshmi, K., Introduction to coffee, in Recent Trends in Soft Beverages, L.G.M. Rao, Ramalakshmi, K., Editor 2011, Woodhead Publishing India PVT. LTD. p. 3-25.

16. Casa Brazil Coffee. Anatomy of the Coffee Fruit and Bean. 2018 [cited $201812^{\text {th }}$ August]; Available from: http://www.casabrasilcoffees.com/learn/anatomy-of-thecoffee-fruit-and-bean/.

17. Esquivel, P., Jiménez, V.M., Functional properties of coffee and coffee by-products. Food Research International, 2012. 46(2): p. 488-495.

18. Oliveira, L.S., Franca, A.S., An Overview of the Potential Uses for Coffee Husks, in Coffee in Health and Disease Prevention, V. Preedy, Editor 2015, Elsevier. p. 283291.

19. Murthy, P.S., Naidu, M.M., Sustainable management of coffee industry by-products and value addition-A review. Resources, Conservation and Recycling, 2012. 66: p. 4558.

20. Jenkins, R.W., Stageman, N.E., Fortune, C.M., Chuck, C.J., Effect of the Type of Bean, Processing, and Geographical Location on the Biodiesel Produced from Waste Coffee Grounds. Energy \& Fuels, 2014. 28(2): p. 1166-1174.

21. Dang, C.-H., Nguyen, T-D., Physicochemical Characterization of Robusta Spent Coffee Ground Oil for Biodiesel Manufacturing. Waste and Biomass Valorization, 2018. Article in Press: p. 1-10.

22. Costa, A.S.G., Alves, R.C., Vinha, A.F., Barreira, S.V.P., Nunes, M.A., Cunha, L.M., Oliveira, M.B.P.P., Optimization of antioxidants extraction from coffee silverskin, a roasting by-product, having in view a sustainable process. Industrial Crops and Products, 2014. 53: p. 350-357.

23. Mata, M.T., Martins, A.A., Caetano, N.S, Bio-refinery approach for spent coffee grounds valorization. Bioresource Technology, 2018. 247: p. 1077-1084.

24. Peshev, D., Mitev, D., Peeva, L., Peev, G., Valorization of spent coffee grounds-A new approach. Separation and Purification Technology, 2018. 192: p. 271-277.

25. Kovalcik, A., Obruca, S., Marova, I., Valorization of spent coffee grounds: A review. Food and Bioproducts Processing, 2018. 110: p. 104-119.

26. Boyadzhieva, S., Angelov, G., Georgieva, S., Yankov, D., Characterization of polyphenol content and antioxidant capacity of spent coffee grounds. Bulgarian Chemical Communications, 2018. 50(C): p. 85-89. 
27. Loyao Jr, A.S., Villasica, S.L.G., Pena, P.L.L.D., Go, A.W. , Extraction of lipids from spent coffee grounds with non-polar renewable solvents as alternative. Industrial Crops and Products, 2018. 119: p. 152-161.

28. Go, Y.W., Yeom, S.H., Statistical Analysis and Optimization of Biodiesel Production from Waste Coffee Grounds by a Two-step Process. Biotechnology and Bioprocess Engineering, 2017. 22: p. 440-449.

29. Low, J.H., Wan Abdul Rahman, W.. Jamaluddin, J., The influence of extraction parameters on spent coffee grounds as a renewable tannin resource. Journal of Cleaner Production, 2015. 101: p. 222-228.

30. Kookos, I.K., Technoeconomic and environmental assessment of a process for biodieselproduction from spent coffee grounds (SCGs). Resources, Conservation \& Recycling, 2018. 134: p. 156-164.

31. Bonita, J.S., Mandarano, M., Shuta, D., Vinson, J., Coffee and cardiovascular disease: in vitro, cellular, anima, and human studies2007. Pharmacological Research, 2007. 55(3): p. 187-198.

32. Anastopoulos, I., Karamesouti, M., Mitropoulos, A.C., Kyzas, G.Z., A review for coffee adsorbents. Journal of Molecular Liquids, 2017. 229: p. 555-565.

33. Bio-bean. Waste Collection. 2018 [cited $201820^{\text {th }}$ August]; Available from: https://www.bio-bean.com/collection/\#1493904724118-c9fdd14b-90b6.

34. Bio-bean. The UK produces 500,000 tonnes of waste coffee grounds each year. 2018 [cited $2018 \quad 12^{\text {th }} \quad$ August]; Available from: https://www.biobean.com/essential_grid/coffee-grounds/.

35. Chanakya, H.N., Alwis, A.A.P., Environmental Issues and Management in Primary Coffee Processing. Process Safety and Environmental Protection, 2004. 82(4): p. 291300 .

36. Tucker, R., Biogas derived from...coffee? Renewable Energy Focus, 2014. 15(5): p. 14-15.

37. Jenkins, R.W., Renewable liquid transport fuels from microbes and waste resources, in Centre for Sustainable Chemical Technologies, Department of Chemical Engineering2014, University of Bath. p. 252.

38. Getachew, A.T., Chun, B.S., Influence of pretreatment and modifiers on subcritical water liquefaction of spent coffee grounds: A green waste valorization approach. Journal of Cleaner Production, 2017. 142: p. 3719-3727.

39. Brazinha, C., Cadima, M., Crespo, J.G., Valorization of spent coffee through membrane processing. Journal of Food Engineering, 2015. 149: p. 123-130.

40. Martinez-Saez, N., García, A.T., Pérez, I.D., Rebollo-Hernanz, M., Mesías, M., Morales, F.J., Martín-Cabrejas, M.A., del Castillo, M.D., Use of spent coffee grounds as food ingredient in bakery products. Food Chemistry, 2017. 216: p. 114-122.

41. Koh, E., Hong, K.H., Preparation and properties of wool fabrics dyed with spent coffee ground extract. Textile Research Journa, 2017: p. 1-7. 
42. Somnuk, K., Eawlex, P., Prateepchaikul, G., Optimization of coffee oil extraction from spent coffee grounds using four solvents and prototype-scale extraction using circulation process. Agriculture and Natural Resources, 2017. 51(3): p. 181-189.

43. Simões, J., Nunes, F.M., Domingues, M.R., Coimbra, M.A., Extractability and structure of spent coffee ground polysaccharides by roasting pre-treatments. Carbohydrate Polymers, 2013. 97(1): p. 81-89.

44. Akgün, N.A., Bulut, H., Kikic, I., Solinas, D., Extraction Behavior of Lipids Obtained from Spent Coffee Grounds Using Supercritical Carbon Dioxide. Chemical engineering \& Technology, 2014. 37(11): p. 1975-1981.

45. Ballesteros, L.F., Teixeiraa, J.A., Mussatto, S.I., Extraction of polysaccharides by autohydrolysis of spent coffee grounds and evaluation of their antioxidant activity. Carbohydrate Polymers, 2017. 157: p. 258-266.

46. Passos, C.P., Coimbra, M.A.,, Microwave superheated water extraction of polysaccharides from spent coffee grounds. Carbohydrate Polymers, 2013. 94(1): p. 626-633.

47. Simões, J., Maricato, E., Nunes, F.M., Domingues, M.R., Coimbra, M.A., Thermal stability of spent coffee ground polysaccharides: Galactomannans and arabinogalactans. Carbohydrate Polymers, 2014. 101: p. 256-264.

48. Banerjee, A., Singh, V., Solanki, K., Mukherjee, J., Gupta, M.N., Combi-protein coated microcrystals of lipases for production of biodiesel from oil from spent coffee grounds. Sustainable Chemical Processes, 2013. 1(14): p. 1-9.

49. Bendall, S., Birdsall-Wilson, M., Jenkins, R., Chew, Y.M.J., Chuck, C.J., Showcasing Chemical Engineering Principles through the Production of Biodiesel from Spent Coffee Grounds. Journal of Chemical Education, 2015. 92(4): p. 683-687.

50. Caetano, N.S., Silva, V.F.M., Mata, T.M., Valorization of Coffee Grounds for Biodiesel Production. Chemical Engineering Transactions, 2012. 26: p. 267-272.

51. Caetano, N.S., Silva, V.F.M., Melo, A.C., Martins, A.A., Mata, T.M., Spent coffee grounds for biodiesel production and other applications. Clean Technologies and Environmental Policy, 2014. 16(7): p. 1423-1430.

52. Haile, M., Asfaw, A., Asfaw, N., Investigation of Waste Coffee Ground as a Potential Raw Material for Biodiesel Production. International Journal of Renewable Energy Research, 2013. 3(4): p. 854-860.

53. Kwon, E.E., Yi, H., Jeon, Y.J., Sequential co-production of biodiesel and bioethanol with spent coffee grounds. Bioresource Technology, 2013. 136: p. 475-480.

54. Liu, Y., Tu, Q., Knothe, G., Lu, M., Direct transesterification of spent coffee grounds for biodiesel production. Fuel, 2017. 199: p. 157-161.

55. Misra, M. Waste coffee grounds offer new source of biodiesel fuel. 2017 [cited 2017 $5^{\text {th }} \quad$ September]; Available from: https://www.acs.org/content/acs/en/pressroom/newsreleases/2008/december/wastecoffee-grounds-offer-new-source-of-biodiesel-fuel.html. 
56. Oliveira, L.S., Franca, A.S., Camargos, R.R.S., Ferraz, V.P., Coffee oil as a potential feedstock for biodiesel production. Bioresource Technology, 2008. 99: p. 3244-3250.

57. Park, J., Kim, B., Lee, J.W., In-situ transesterification of wet spent coffee grounds for sustainable biodiesel production. Bioresource Technology, 2016. 221: p. 55-60.

58. Patra, C.J., Kumaran, P., Praveen, R., Kumar, A.S., Production of biodiesel from spent coffee grounds by transertification and its byproducts as fuel additives. International Journal of Chemical Sciences, 2016. 14(S2): p. 590-596.

59. Rocha, M.V.P., de Matos, L.J.B.L., de Lima, L.P., da Silva Figueiredo, P.M., Lucena, I.L., Fernandes, F.A.N., Gonçalves, L.R.B., Ultrasound-assisted production of biodiesel and ethanol from spent coffee grounds. Bioresource Technology, 2014. 167: p. 343-348.

60. Swanepoel, W., Karmee, S.K., Marx, S., Biocatalytic Production of Biodiesel from Spent Coffee Grounds, in International Conference on Advances in Science, Engineering, Technology and Natural Resources (ICASETNR-16)2016: Parys (South Africa).

61. Tuntiwiwattanapun, N., Mononoc, E., Wiesenbornc, D., Tongcumpou, C., In-situ transesterification process for biodiesel production using spent coffee grounds from the instant coffee industry. Industrial Crops and Products, 2017. 102: p. 23-31.

62. Vardon, D.R., Moser, B.R., Zheng, W., Witkin, K., Evangelista, R.L., Strathmann, T.J., Rajagopalan, K., Sharma, B.K., Complete Utilization of Spent Coffee Grounds To Produce Biodiesel, Bio-Oil, and Biochar. ACS Sustainable Chem. Eng, 2013. 1(10): p. 1286-1294.

63. Blinova, L., Bartosova, A., Sirotiak, M., Biodiesel production from spent coffee grounds. The Journal of Slovak University of Technology, 2017. 25(40): p. 113-121.

64. Al-Hamamre, Z., Foerster, S., Hartmann, F., Kröger, M., Kaltschmitt, M., Oil extracted from spent coffee grounds as a renewable source for fatty acid methyl ester manufacturing. Fuel, 2012. 96: p. 70-76.

65. Deligiannis, A., Papazafeiropoulou, A., Anastopoulos, G., Zannikos, F. Waste Coffee Grounds as an Energy Feedstock. in The $3^{\text {rd }}$ International CEMEPE \& SECOTOX Conference. 2011.

66. Haile, M., Integrated volarization of spent coffee grounds to biofuels. Biofuel Research Journal, 2014. 2: p. 65-69.

67. Boualdab, C., Valorization of waste coffee grounds in to biodiesel: final report, 2016, Al Akhawayn University.

68. Calixto, F., Fernandes, J., Couto, R., Hernandez, E.J., Najdanovic-Visak, V.,Simoes, P.C., Synthesis of fatty acid methyl esters via direct transesterification with methanol/carbon dioxide mixtures from spent coffee grounds feedstock. Green Chemistry, 2011. 13(5): p. 1196-1202.

69. Lui, Y., Making biodiesel from spent coffee grounds through in situ transesterification, in Department of Biomedical, Chemical, and Environmental Engineering2015, University of Cincinnati. p. 92. 
70. Sakuragi, K., Li , P., Otaka, M., Makino, H., Recovery of Bio-Oil from Industrial Food Waste by Liquefied Dimethyl Ether for Biodiesel Production. Energies, 2016. 9: p. 106.

71. Sarno, M., Luliano, M., Active biocatalyst for biodiesel production from spent coffee ground. Bioresource Technology, 2018. 266: p. 431-438.

72. Son, J., Kim, B., Park, J., Yang, J., Lee, J.W., Wet in situ transesterification of spent coffee grounds with supercritical methanol for the production of biodiesel. Bioresource Technology, 2018. 259: p. 465-468.

73. Park, J., Kim, B., Son, J., Lee, J.W., Solvo-thermal in situ transesterification of wet spent coffee grounds for the production of biodiesel. Bioresource Technology, 2018. 249: p. 494-500.

74. Najdanovic-Visak, V., Lee, F.Y-L., Tavares, M.T., Armstrong, A., Kinetics of extraction and in situ transesterification of oils from spent coffee grounds. Journal of Environmental Chemical Engineering, 2017. 5: p. 2611-2616.

75. La, J.-H., Lee, S-B, Lee, J-D., Optimization of Biodiesel Synthesis Process Using Spent Coffee Grounds. Applied Chemistry for Engineering, 2011. 22(1): p. 72-76.

76. Iličković, Z., Đonlagić, M., Redžić, E., Secondary raw materials in biodiesel production-Spent coffee grounds. Technologica Acta, 2009. 2(1): p. 19-25.

77. Tuntiwiwattanapun, N., Tongcumpou, C., Sequential extraction and reactive extraction processing of spent coffee grounds: An alternative approach for pretreatment of biodiesel feedstocks and biodiesel production. Industrial Crops and Products, 2018. 117: p. 359-365.

78. Liu, Y., Lu, M., Tu, Q. Reuse of spent coffee grounds to produce biodiesel and activated carbons. in Proceedings of the Air and Waste Management Association's Annual Conference and Exhibition, AWMA. 2014. Air and Waste Management Association.

79. Haile, M., Biofuel Energy: spent coffee grounds biodiesel, bioethanol and solid fuel2014: Anchor Academic Publishing. 108.

80. Caetano, N.S., Caldeira, D., Martins, A.A., Mata, T.M., Valorisation of Spent Coffee Grounds: Production of Biodiesel via Enzymatic Catalysis with Ethanol and a Cosolvent. Waste and Biomass Valorization, 2017. 8: p. 1981-1994.

81. Atabani, A.E., Shobana, S., Mohammed, M.N., Uğuz, G., Kumar, G., Arvindnarayan, S., Aslam, M., Al-Muhtaseb, A.H., Integrated valorization of waste cooking oil and spent coffee grounds for biodiesel production: Blending with higher alcohols, FT-IR, TGA, DSC and NMR characterizations. Fuel, 2019. 244: p. 419-430.

82. Mueanmas, C., Nikhom, R., Petchkaew, A., Lewkittayakorn, J., Prasertsit, K., Extraction and esterification of waste coffee grounds oil as non-edible feedstock for biodiesel production. Renewable Energy, 2019. 133: p. 1414-1425.

83. Kang, S.B., Oh, H.Y., Kim, J.J., Choi, K.S., Characteristics of spent coffee ground as a fuel and combustion test in a small boiler $(6.5 \mathrm{~kW})$. Renewable Energy, 2017. 113: p. $1208-1214$. 
84. Silva, M.A., Nebra, S.A., Silva, M.J.M., Sanches, C.G., The use of biomass residues in the brazilian soluble coffee industry. Biomass and Bioenergy, 1998. 14(5/6): p. 457467.

85. Gómez-de la Cruz, F.J., Cruz-Peragón, F., Casanova-Peláez, P.J., Palomar-Carnicero, J.M., A vital stage in the large-scale production of biofuels from spent coffee grounds: The drying kinetics. Fuel Processing Technology, 2015. 130: p. 188-196.

86. Jeguirim, M., Limousy, L., Dutournie, P., Pyrolysis kinetics and physicochemical properties of agropellets produced from spent ground coffee blended with conventional biomass. Chemical Engineering Research and Design, 2014. 92(10): p. 1876-1882.

87. Limousy, L., Jeguirim, M., Dutournié, P., Kraiem, N., Lajili, M., Said, R., Gaseous products and particulate matter emissions of biomass residential boiler fired with spent coffee grounds pellets. Fuel, 2013. 107: p. 323-329.

88. Ciesielczuk, T., Karwaczyńska, U., Sporek, M., The possibility of disposing of spent coffee ground with energy recycling. J. Ecol. Eng, 2015. 16: p. 133-138.

89. Potip, S., Wongwuttanasatian, T., Combustion characteristics of spent coffee ground mixed with crude glycerol briquette fuel. Combustion Science and Technology, 2018. Article in Press.

90. Yang, L., Nazari, L., Yuan, Z., Corscadden, K., Xu, C., He, Q., Hydrothermal liquefaction of spent coffee grounds in water medium for bio-oil production. Biomass and Bioenergy, 2016. 86: p. 191-198.

91. Zanella, E., Zassa, M.D., Navarini, L., Canu, P., Low-Temperature Co-pyrolysis of Polypropylene and Coffee Wastes to Fuels. Energy \& Fuels, 2013. 27(3): p. 13571364.

92. Kan, T., Strezov, V., Evans, T., Catalytic Pyrolysis of Coffee Grounds Using NiCuImpregnated Catalysts. Energy \& Fuels, 2014. 28(1): p. 228-235.

93. Bok, J.P., Choi, H.S., Choi, Y.S., Park, H.C., Kim, S.J., Fast pyrolysis of coffee grounds: Characteristics of product yields and biocrude oil quality. Energy, 2012. 47: p. 17-24.

94. Kelkar, S., Saffron, C.M., Chai, L., Bovee, J., Stuecken, T.R., Garedew, M., Li, Z., Kriegel, R.M., Pyrolysis of spent coffee grounds using a screw-conveyor reactor. Fuel Processing Technology, 2015. 137: p. 170-178.

95. Li, X., Strezov, V., Kan, T., Energy recovery potential analysis of spent coffee grounds pyrolysis products. Journal of Analytical and Applied Pyrolysis, 2014. 110: p. 79-87.

96. Primaz, C.T., Schena, T., Lazzari, E., Caramãoa, E.B., Jacques, R.A., Influence of the temperature in the yield and composition of the bio-oil from the pyrolysis of spent coffee grounds: Characterization by comprehensive two dimensional gas chromatography. Fuel, 2018. 232: p. 572-580. 
97. Yang, L., He, Q., Havard a, P., Corscadden, K., Xu, C., Wang, X., Co-liquefaction of spent coffee grounds and lignocellulosic feedstocks. Bioresource Technology, 2017. 237: p. 108-121.

98. Cho, D.-W., Lee, J., Yoon, K., Ok, Y.S., Kwon, E.E., Song, H., Pyrolysis of FeCl $3^{-}$ pretreated spent coffee grounds using $\mathrm{CO}_{2}$ as a reaction medium. Energy Conversion and Management, 2016. 127: p. 437-442.

99. Luz, F.C., Cordiner, S., Manni, A., Mulone, V., Rocco, V., Biomass fast pyrolysis in screw reactors: Prediction of spent coffee grounds bio-oil production through a monodimensional model. Energy Conversion and Management, 2018. 168: p. 98-106.

100. Ktori, R., Kamaterou, P., Zabaniotou, A., Spent coffee grounds valorization through pyrolysis for energy and materials production in the concept of circular economy. Materials Today: Proceedings, 2018. 5(14(1)): p. 27582-27588.

101. Burniol-Figols, A., Ceniana, K., Skiadas, I.V., Gavala, H.N., Integration of chlorogenic acid recovery and bioethanol production from spent coffee grounds. Biochemical Engineering Journal, 2016. 116: p. 54-64.

102. Sampaio, A.M., I.M., Spent coffee grounds: a potential feedstock for ethanol production, in Symposium on Biotechnology for Fuels and Chemicals2014: Clearwater Beach, FL.

103. Kim, J., Kim, H., Baek, G., Lee, C., Anaerobic co-digestion of spent coffee grounds with different waste feedstocks for biogas production. Waste Management, 2017. 60: p. 322-328.

104. Vítěz, T., Koutný, T., Šotnar, M., Chovanec, J., On the spent coffee grounds biogas production. Acta Universitatis Agriculturae et Silviculturae Mendelianae Brunensis, 2016. 64(4): p. 1279-1282.

105. Luz, F.C., Cordinera, S., Manni, A., Mulone, V., Rocco, V., Anaerobic Digestion of Liquid Fraction Coffee Grounds at Laboratory Scale: Evaluation of the Biogas Yield. Energy Procedia, 2017. 105: p. 1096-1101.

106. Qiao, W., Takayanagi, K., Shofie, M., Niu, Q., Yu, H.Q., Li, Y-Y., Thermophilic anaerobic digestion of coffee grounds with and without waste activated sludge as cosubstrate using a submerged AnMBR: System amendments and membrane performance. Bioresource Technology, 2013. 150: p. 249-258.

107. Lane, A.G., Anaerobic digestion of spent coffee grounds. Biomass, 1983. 3(4): p. $247-$ 268.

108. Girotto, F., Lavagnolo, M.C., Pivato, A., Spent Coffee Grounds Alkaline Pretreatment as Biorefinery Option to Enhance their Anaerobic Digestion Yield. Waste and Biomass Valorization, 2017.

109. Kim, J., Kim, H., Lee, C., Ulva biomass as a co-substrate for stable anaerobic digestion of spent coffee grounds in continuous mode. Bioresource Technology, 2017. 241: p. 1182-1190. 
110. Kim, D., Kim, J., Lee, C., Effect of Mild-Temperature Thermo-Alkaline Pretreatment on the Solubilization and Anaerobic Digestion of Spent Coffee Grounds. Energies, 2018. 11(4): p. 865.

111. Girotto, F., Pivato, A., Cossu, R., Nkeng, G.E., Lavagnolo, M.C., The broad spectrum of possibilities for spent coffee grounds valorisation. Journal of Material Cycles and Waste Management, 2018. 20: p. 695-701.

112. Döhlert, P., Weidauer, M., Enthaler, S., Spent coffee ground as source for hydrocarbon fuels. Journal of Energy Chemistry, 2016. 25: p. 146-152.

113. Phimsen, S., Kiatkittipong, W., Yamada, H., Tagawa, T., Kiatkittipong, K., Laosiripojana, N., Assabumrungrat, S., Oil extracted from spent coffee grounds for bio-hydrotreated diesel production. Energy Conversion and Management, 2016. 126: p. 1028-1036.

114. Acevedo, F., Rubilar, M., Scheuermann, E., Cancino, B., Uquiche, E., Garcés, M., Inostroza, K., Shene, C. Bioactive compounds of spent coffee grounds, a coffee industrial residue. in III Symposium on agricultural and agroindustrial waste management. 2013. Sao Pedro, SP, Brazil.

115. Bravo, J., Juániz, I., Monente, C., Caemmerer, B., Kroh, L.W., De Peña, M.P., Cid, C., Evaluation of Spent Coffee Obtained from the Most Common Coffeemakers as a Source of Hydrophilic Bioactive Compounds. Journal of Agricultural and Food Chemistry, 2012. 60(51): p. 12565-12573.

116. Scully, D.S., Jaiswal, A.K., Abu-Ghannam, N., An Investigation into Spent Coffee Waste as a Renewable Source of Bioactive Compounds and Industrially Important Sugars. Bioengineering, 2016. 3(33).

117. Caballero-Galván, A.S., Restrepo-Serna, D.L., Ortiz-Sánchez, M., Cardona-Alzate, C.A., Analysis of Extraction Kinetics of Bioactive Compounds from Spent Coffee Grounds (Coffea arábica). Waste and Biomass Valorization, 2018. Article in Press.

118. Le, P.T.K., Vu, Q.T.H., Nguyen, Q.T.V., Tran, K.A., Le, K.A., Spent Coffee Grounds as a Valuable Source of Bioactive Compounds and Bioenergy. Chemical Engineering Transactions, 2017. 56: p. 37-42.

119. Low, J.H., Wan Abdul Rahman, W., Jamaluddin, J., Structural elucidation of tannins of spent coffee grounds by CP-MAS $13 C$ NMR and MALDI-TOF MS. Industrial Crops and Products, 2015. 69: p. 456-461.

120. Mayanga-Torres, P.C., Lachos-Perez, D., Rezende, C.A., Prado, J.M., Ma, Z., Tompsett, G.T., Timko, M.T., Forster-Carneiro, T., Valorization of coffee industry residues by subcritical water hydrolysis: Recovery of sugars and phenolic compounds. The Journal of Supercritical Fluids, 2017. 120: p. 75-85.

121. Oseguera-Sánchez, E., Cerón-García, A., César Ozuna, C., Bioactive Compound Content and Antioxidant Capacity of Solid Processing Waste from Organic and Conventional Coffee Farming, in CSBE/SCGAB 2017 Annual Conference2017: Canad Inns Polo Park, Winnipeg, MB, Canada. 
122. Mussatto, S.I., Carneiro, L.M., Silva, J.P.A., Roberto, I.C., Teixeira, J.A., A study on chemical constituents and sugars extraction from spent coffee grounds. Carbohydrate Polymers, 2011. 83(2): p. 368-374.

123. Monente, C., Bravo, J., Vitas, A.I., Arbillaga, L., de pena, M.P., Cid, C., Spent Coffee Grounds as a source of bioactive compounds, in 3rd Conference ISEKI2014: Athens, Greece.

124. Ballesteros, L.F., Cerqueira, M.A., Teixeira, J.A., Mussatto, S.I., Characterization of polysaccharides extracted from spent coffee grounds by alkali pretreatment. Carbohydrate Polymers, 2015. 127: p. 347-354.

125. Hudeckova, H., Neureiter, M., Obruca, S., Frühauf, S., Marova, I., Biotechnological conversion of spent coffee grounds into lactic acid Letters in Applied Microbiology, 2018. 66(4): p. 306-312.

126. Tian, T., Freeman, S., Corey, M., German, J.B., Barile, D., Chemical Characterization of Potentially Prebiotic Oligosaccharides in Brewed Coffee and Spent Coffee Grounds. Journal of Agricultural and Food Chemistry, 2017. 65: p. 2784-2792.

127. Ali, H.S., Mansour, A.F., Kamil, M.M., Hussein, A.M.S., Formulation of Nutraceutical Biscuits Based on Dried Spent Coffee Grounds. International Journal of Pharmacology, 2018. 14(4): p. 584-594.

128. Ribeiro, H.M., Allegro, M., Marto, J., Bruno Pedras, B., Oliveira, N.G., Paiva, A., Barreiros, S., Gonçalves, L.M., Simões, P., Converting Spent Coffee Grounds into Bioactive Extracts with Potential Skin Antiaging and Lightening Effects. ACS Sustainable Chemical Engineering, 2018. 6(5): p. 6289-6295.

129. Getachew, A.T., Cho, Y.J., Chun, B.S., Effect of Pretreatments on Isolation of Bioactive Polysaccharides from Spent Coffee Grounds Using Subcritical Water. International Journal of Biological Macromolecules, 2018. 109: p. 711-719.

130. Le, P.T.K., Vu, Q.T.H., Nguyen, Q.T.V., Tran, K.A., Le, K.A., Extraction and Evaluation the Biological Activities of Oil from Spent Coffee Grounds. Chemical Engineering Transactions, 2017. 56: p. 1729-1734.

131. Andradea, K.S., Goncalvez, R.T., Maraschin, M., Ribeiro-do-Valle, R.M., Martínez, J., Ferreira, S.R.S., Supercritical fluid extraction from spent coffee grounds and coffee husks: Antioxidant activity and effect of operational variables on extract composition. Talanta, 2012. 88: p. 544-552.

132. Ballesteros, L.F., Ramirez, M.J., Orrego, C.E., Teixeira, J.A., Mussatto, S.I., Optimization of autohydrolysis conditions to extract antioxidant phenolic compounds from spent coffee grounds. Journal of Food Engineering, 2017. 199: p. 1-8.

133. Mussatto, S.I., Ballesteros, L.F., Martins, S., Teixeira, J.A., Extraction of antioxidant phenolic compounds from spent coffee grounds. Separation and Purification Technology, 2011. 83(15): p. 173-179.

134. Panzella, L., Pérez-Burillo, S.., Pastoriza, S., Martín, M.A., Cerruti, P., Goya, L., Ramos, S., Rufián-Henares, J.A., Napolitano, A., d'Ischia, M., High Antioxidant Action and Prebiotic Activity of Hydrolyzed Spent Coffee Grounds (HSCG) in a 
Simulated Digestion-Fermentation Model: Toward the Development of a Novel Food Supplement. J. Agric. Food Chem, 2017. 65(31): p. 6452-6459.

135. Páscoa, R.N.M.J., Magalhães, L.M., Lopes, J.A., FT-NIR spectroscopy as a tool for valorization of spent coffee grounds: Application to assessment of antioxidant properties. Food Research International 51 (2013), 2013. 51: p. 579-586.

136. Paradkar, M.M., Irudayaraj, J., Rapid determination of caffeinecontent in soft drinks using FTIR-ATR spectroscopy. Food Chemistry, 2002. 78(2): p. 261-266.

137. Cruz, R., Gomes, T., Ferreira, A., Mendes, E., Baptista, P., Cunha, S., Pereira, J.A., Ramalhosa, E., Casal, S., Antioxidant activity and bioactive compounds of lettuce improved by espresso coffee residues. Food Chemistry, 2014. 145: p. 95-101.

138. Shang, Y.-F., Xu, J-L., Lee, W-J., Um, B-H., Antioxidative polyphenolics obtained from spent coffee grounds by pressurized liquid extraction. South African Journal of Botany, 2017. 109: p. 75-80.

139. Xu, H., Wang, W., Liu, X., Yuan, F., Gao, Y., Antioxidative phenolics obtained from spent coffee grounds (Coffea arabica L.) by subcritical water extraction. Industrial Crops and Products, 2015. 76: p. 946-954.

140. Belviso, S., Ghirardello, D., Rantsiou, K., Giordano, M., Bertolino, M., Borgogna, D., Cavallero, M.C., Bello, B.D., Cena, C., Rolle, L., Zeppa, G., Gerbi, V., Phytochemical and microbiological stability of spent espresso coffee grounds in capsules. Food Research International, 2014. 61: p. 93-99.

141. Bravo, J., Monente, C., Juániz, I., De Peña, M.P., Cid, C., Influence of extraction process on antioxidant capacity of spent coffee. Food Research International, 2013. 50: p. 610-616.

142. Zuorro, A., Lavecchia, R., Spent coffee grounds as a valuable source of phenolic compounds and bioenergy. Journal of Cleaner Production, 2012. 34: p. 49-56.

143. Pujol, D., Liua, C., Gominhoc, J., Olivella, M.A., Fiol, N., Villaescusa, I., Pereira, H., The chemical composition of exhausted coffee waste. Industrial Crops and Products, 2013. 50: p. 423-429.

144. Wu, C.-H., Modulation of the interface between polyester and spent coffee grounds in polysaccharide membranes: Preparation, cell proliferation, antioxidant activity and tyrosinase activity. Materials Science and Engineering: C, 2017. 78: p. 530-538.

145. Ballesteros, L.F., Teixeira, J.A., Mussatto, S.I., Chemical, Functional, and Structural Properties of Spent Coffee Grounds and Coffee Silverskin. Food and Bioprocess Technology, 2014. 7(12): p. 3493-3503.

146. Pavlovic', M.D., Buntic', A.V., Šiler-Marinkovic', S.S., Dimitrijevic'-Brankovic, S.I., Ethanol influenced fast microwave-assisted extraction for natural antioxidants obtaining from spent filter coffee. Separation and Purification Technology, 2013. 118: p. 503-510.

147. Ramalakshmi, K., Rao, L.J.M., Takano-Ishikawa, Y., Goto, M., Bioactivities of lowgrade green coffee and spent coffee in different in vitro model systems. Food Chemistry, 2009. 115: p. 79-85. 
148. Mitev, D., Peshev, D., Peev, G., Peeva, L., Antioxidant activity of membranefractionated coffee extracts in dependence of the storage conditions. Journal of Physics: Conference Series, 2016. 764(1): p. 012007.

149. Boyadzhiev, L., Angelov, G., Georgieva, S., Lazarova, M., Popova, T. Spent coffee grounds-a neglected source of antioxidants. in Food Science, Engineering and Technologies-2010 Conference. 2010. Plovdiv, Bulgaria.

150. Yoo, D.E., Jeong, K.M., Han, S.Y., Kim, E.M., Jin, Y., Lee, J., Deep eutectic solventbased valorization of spent coffee grounds. Food Chemistry, 2018. 255: p. 357-364.

151. Todaka, M., Kowhakul, W., Masamoto, H., Shigematsu, M., Improvement of oxidation stability of biodiesel by an antioxidant component contained in spent coffee grounds. Biofuels, 2018. Article in Press: p. 1-9.

152. Machado, E.M.S., Bernardo-Gil, M.G., Teixeira, J.A., Mussatto, S.I., Extraction of Value-added Compounds from Spent Coffee Grounds using Supercritical Fluid, in $12^{\text {th }}$ International Chemical and Biological Engineering 2014: Porto, Portugal.

153. Shen, K., Gondal, M.A., Removal of hazardous Rhodamine dye from water by adsorption onto exhausted coffee ground. Journal of Saudi Chemical Society, 2017. 21: p. S120-S127.

154. Tokimoto, T., Kawasaki, N., Nakamura, T., Akutagawa, J., Tanada, S., Removal of lead ions in drinking water by coffee grounds as vegetable biomass. Journal of Colloid and Interface Science, 2005. 281(1): p. 56-61.

155. Cholakov, G., Toteva, V., Nikolov, R., Uzunova, Sn., Yanev, St., Extracts from Coffee by-Products as Potential Raw Materials for Fuel Additives and Carbon Adsorbents. J. Chem. Technol. Metallurgy, 2013. 48(5): p. 497-504.

156. Franca, A.S., Oliveira, L.S., Ferreira, M.E., Kinetics and equilibrium studies of methylene blue adsorption by spent coffee grounds. Desalination, 2009. 249: p. 267272.

157. Kante, K., Nieto-Delgado, C., Rangel-Mendez, J.R., Bandosz, T.J., Spent coffee-based activated carbon: Specific surface features and their importance for $\mathrm{H}_{2} \mathrm{~S}$ separation process. Journal of Hazardous Materials, 2012. 201-202: p. 141-147.

158. Ma, X., Ouyang, F., Adsorption properties of biomass-based activated carbon prepared with spent coffee grounds and pomelo skin by phosphoric acid activation. Applied Surface Science, 2013. 268: p. 566-570.

159. Plaza, M.G., González, A.S., Pevida, C., Pis, J.J., Rubiera, F., Valorisation of spent coffee grounds as $\mathrm{CO}_{2}$ adsorbents for postcombustion capture applications. Applied Energy, 2012. 99: p. 272-279.

160. Jung, K.-W., Choi, B-H., Hwang, M-J., Jeong, T-U., Ahn, K-H., Fabrication of granular activated carbons derived from spent coffee grounds by entrapment in calcium alginate beads for adsorption of acid orange 7 and methylene blue. Bioresource Technology, 2016. 219: p. 185-195.

161. Pavlović, M.D., Buntić, A.V., Šiler-Marinković, S.S., Antonović, D.G., Milutinović, M.D., Radovanović, N.R., Dimitrijević-Branković, S.I., Spent Coffee Grounds as 
Adsorbents for Pesticide Paraquat Removal from its Aqueous Solutions, in International Conference on Civil, Biological and Environmental Engineering (CBEE2014)2014: Istanbul (Turkey).

162. Mat, S.S.A., Zuber, S.Z.H.S., Rahim, S.K.E.A., Sohaimi, K.S.A., Halim, N.A., Zainudin, N.F., Yusoff, N.A., Rohaizad, N.M., Ishak, N.H., Anuar, A., Sarip, M.S.M., Malachite Green Adsorption by Spent Coffee Grounds, in IOP Conf. Series: Materials Science and Engineering 318 (2018) 0120152018, IOP Publishing.

163. Lavecchia, R., Medici, F., Patterer, M.S., Zuorro, A., Lead removal from water by adsorption on spent coffee grounds. Chemical Engineering Transactions, 2016. 47: p. 295-300.

164. Safarik, I., Horska, K., Svobodova, B., Safarikova, M., Magnetically modified spent coffee grounds for dyes removal. European Food Research and Technology, 2012. 234: p. 345-350.

165. Gonzalez, A.s., Plaza, M.G., Pis, J.J., Rubiera, F., Pevida, C., Post-combustion $\mathrm{CO}_{2}$ capture adsorbents from spent coffee grounds. Energy Procedia, 2013. 37: p. 134-141.

166. Kim, M.-S., Min, H-G., Koo, N., Park, J., Lee, S-H., Bak, G-I., Kim, J-G., The effectiveness of spent coffee grounds and its biochar on the amelioration of heavy metals-contaminated water and soil using chemical and biological assessments. Journal of Environmental Management, 2014. 146: p. 124-130.

167. Cruz, R., Mendes, E., Torrinha, A., Morais, S., Pereira, J.A., Baptista, P., Casal, S., Revalorization of spent coffee residues by a direct agronomic approach. Food Research International, 2015. 73: p. 190-196.

168. Gomes, T., Pereira, J.A., Ramalhosa, E., Casal, S., Baptista, P., Effect of fresh and composted spent coffee grounds on lettuce growth, photosynthetic pigments and mineral composition, in VII Congreso Ibérico de Agroingenieria y Ciencias Horticolas2013: Madrid, Spain.

169. Liu, K., Price, G.W., Evaluation of three composting systems for the management of spent coffee grounds. Bioresource Technology, 2011. 102(17): p. 7966-7974.

170. Hachicha, R., Rekik, O., Hachicha, S., Ferchichi, M., Woodward, S., Moncef, N., Cegarra, J., Mechichi, T., Co-composting of spent coffee ground with olive mill wastewater sludge and poultry manure and effect of Trametes versicolor inoculation on the compost maturity. Chemosphere, 2012. 88(6): p. 677-682.

171. Zhang, L., Sun, X., Using cow dung and spent coffee grounds to enhance the twostage co-composting of green waste. Bioresource Technology, 2017. 245(Part A): p. 152-161.

172. Adi, A.J., Noor, Z.M., Waste recycling: Utilization of coffee grounds and kitchen waste in vermicomposting. Bioresource Technology, 2006. 100(2): p. 1027-1030.

173. Sanchez-Hernandez, J.C., Domínguez, J., Vermicompost derived from spent coffee grounds: assessing the potential for enzymatic bioremediation, in Handbook of Coffee Processing By-Products, C. Galanakis, Editor 2017, Elsevier. p. 369-398. 
174. Lee, H.K., Park, Y.G., Jeong, T., Song, Y.S., Green nanocomposites filled with spent coffee grounds. Journal of Applied Polymer Sciene, 2015. 132(23): p. 1-6.

175. Obruca, S., Benesova, P., Petrik, S., Oborna, J., Prikryl, R., Marova, I., Production of polyhydroxyalkanoates using hydrolysate of spent coffee grounds. Process Biochemistry, 2014. 49(9): p. 1409-1414.

176. Obruca, S., Petrik, S., Benesova, P., Svoboda, Z., Eremka, L., Marova, I., Utilization of oil extracted from spent coffee grounds for sustainableproduction of polyhydroxyalkanoates. Applied Microbiology and Biotechnology, 2014. 98(13): p. 8853-5890.

177. Obruca, S., Benesova, P., Kucera, D., Petrik, S., Marova, I., Biotechnological conversion of spent coffee grounds into polyhydroxyalkanoates and carotenoids. New Biotechnology, 2015. 32(6): p. 569-574.

178. Soares, B., Gama, N., Freire, C.S.R., Barros-Timmons, A., Brandão, I., Silva, R., Netoa, C.P., Ferreira, A., Spent coffee grounds as a renewable source for ecopolyols production. Journal of Chemical Technology \& Biotechnology 90(8), 2014. 90(8).

179. Gao, G., Cheong, L-Z., Wang, D., Shen, C., Pyrolytic carbon derived from spent coffee grounds as anode for sodium-ion batteries. Carbon Resources Conversion, 2018. 1(1): p. 104-108.

180. Givens, D.I., Barber, W.P., In vivo evaluation of spent coffee grounds as a ruminant feed. Agricultural Wastes, 1986. 18(1): p. 69-72.

181. Go, A.W., Conag, A.T., Cuizon, D.E.S., Recovery of Sugars and Lipids from Spent Coffee Grounds: A New Approach. Waste and Biomass Valorization, 2016. 7(5): p. 1047-1053.

182. Misra, M., Kondamudi, N., Mohapatra, S.K., John, S.E., High quality biodiesel from spent coffee grounds. Clean Technology, 2008: p. 39-42.

183. Efthymiopoulos, I., Hellier, P., Ladommatos, N., Kay, A., Mills- Lamptey, B., Effect of Solvent Extraction Parameters on the Recovery of Oil From Spent Coffee Grounds for Biofuel Production. Waste and Biomass Valorization, 2017: p. 1-12.

184. Georgieva, S.S., Coelho, J.A.P., Campos, F.C., Robalo, M.P., Stateva, R.P., Green extraction of high added value substances from spent coffee grounds: Preliminary results. Journal of Chemical Technology and Metallurgy, 2018. 53(4): p. 640-646.

185. Efthymiopoulos, I., Hellier, P., Ladommatos, N., Russo-Profili, A., Eveleigh, A., Aliev, A., Kay, A., Mills-Lamptey, B, Influence of solvent selection and extraction temperature on yield and composition of lipids extracted from spent coffee grounds. Industrial Crops and Products, 2018. 119: p. 49-56.

186. Mabona, N., Aboyade, W., Mollagee, M., Mguni, L.L., Effect of moisture content on oil extraction from spent coffee grounds. Energy Sources, Part A: Recovery, Utilization, and Environmental Effects, 2018. 40(5): p. 501-509.

187. Abdullah, M., Koc, A.B., Oil removal from waste coffee grounds using two-phase solvent extraction enhanced with ultrasonication. Renewable Energy, 2013. 50: p. 965-970. 
188. Barbosaa, H.M.A., de Meloa, M.M.R., Coimbrab, M.A., Passosb, C.P., Silva, C.M., Optimization of the supercritical fluid coextraction of oil and diterpenes from spent coffee grounds using experimental design and response surface methodology. Journal of Supercritical Fluids, 2014. 85: p. 165-172.

189. de Melo, M.M.R., Barbosa, H.M.A., Passos, C.P., Silva, C.M., Supercritical fluid extraction of spent coffee grounds: Measurement of extraction curves, oil characterization and economic analysis. The Journal of Supercritical Fluids, 2014. 86: p. $150-159$.

190. Couto, R.M., Fernandes, J., da Silva, M.D.R.G., Simões, P.C., Supercritical fluid extraction of lipids from spent coffee grounds. The Journal of Supercritical Fluids, 2009. 51(2): p. 159-166.

191. Karmee, S.K., Lin, C.S.K, Valorisation of food waste to biofuel: current trends and technological challenges. Sustainable Chemical Processes, 2014. 2(22).

192. Efthymiopoulos, I., Hellier, P., Ladommatos, N., Kay, A., Mills-Lamptey, B., Integrated strategies for water removal and lipid extraction from coffee industry residues. Sustainable Energy Technologies and Assessments, 2018. 29: p. 26-35.

193. Ashok. B., N., K., Jeevanantham, J.K., Bhowmick, P., Malhotra, D., Agarwal, P., An assessment of calophyllum inophyllum biodiesel fuelled diesel engine characteristics using novel antioxidant additives. Energy Conversion and Management, 2017. 148: p. 935-943.

194. Karmee, S.K., Swanepoel, W., Marx, S., Biofuel production from spent coffee grounds via lipase catalysis. Energy Sources, Part A: Recovery, Utilization, and Environmental Effects, 2018. 40(3): p. 294-300.

195. Cruz-Lopez, L., Domingos, I., Ferreira, J., Esteves, B., A new way of using spent coffee ground. Journal of International Scientific Publications, 2017. 5: p. 2017.

196. Neves, L., Ribeiro, R., Oliveira, R., Alves, M.M. Anaerobic Digestion of Coffee waste in ADSW2005. 2005.

197. Neves, L., Oliveira, R., Alves, M.M., Anaerobic co-digestion of coffee waste and sewage sludge. Waste Management, 2006. 26(2): p. 176-181.

198. Dinsdale, R.M., Hwakes, F.R., Hwaked, D.L., The mesophilic and thermophilic anaerobic digestion of coffee waste containing coffee grounds. Water Research, 1996. 30(2): p. 371-377.

199. Vane, L.M., A review of pervaporation for product recovery from biomass fermentation processes. Journal of Chemical Technology and Biotechnology 2005. 80: p. 603-29.

200. Wei, P., Cheng, L-H., Zhang, L., Xu, X-H., Chen, H-1., Gao, C-j, A review of membrane technology for bioethanol production. Renewable and Sustainable Energy Reviews, 2014. 30: p. 388-400.

201. He, Y., Bagley, D.M., Leung, K.T., Liss, S.N., Liao, B-Q., Recent advances in membrane technologies for biorefining and bioenergy production. Biotechnology Advances, 2012. 30: p. 817-858. 
202. Saha, K., Maheswari, U.R., Sikder, J., Chakraborty, S., da Silva, S.S., dos Santos, J.C., Membranes as a tool to support biorefineries: Applications in enzymatic hydrolysis, fermentation and dehydration for bioethanol production. Renewable and Sustainable Energy Reviews, 2017. 74: p. 873-890.

203. Abels, C., Carstensen, F., Wessling, M., Membrane processes in biorefinery applications. Journal of Membrane Science, 2013. 444: p. 285-317.

204. Mehta, G.D., Comparison of membrane processes with distillation for alcohol/ water separation. Journal of Membrane Science, 1982. 12(1): p. 1-26.

205. Leeper, S.A., Tsao, G.T., Membrane separations in ethanol recovery: an analysis of two applications of hyperfiltration. Journal of Membrane Science, 1987. 30(3): p. 289312.

206. Sander, U., Soukup, P.B., Design and operation of pervaporation plant for ethanol dehydration. Journal of Membrane Science, 1988. 36: p. 463-75.

207. Hoekstra, E., Hogendoorn, K.J.A., Wang, X., Westerhof, R.J.M., Kersten, S.R.A., van Swaaij, W.P.M., Groeneveld, M.G., Fast pyrolysis of biomass in a fluidized bed reactor: in situ filtering of the vapors. 2009. 48(10): p. 4744-4756.

208. Javaid, A., Ryan, T., Berg, G., Pan, X., Vispute, T., Bhatia, S.R., Huber, G.W., Ford, D.M., Removal of char particles from fast pyrolysis bio-oil by microfiltration. Journal of Membrane Science, 2010. 363(1-2): p. 120-127.

209. He, H.Y., Guo, X., Zhu, S.L., Comparison of membrane extraction with traditional extraction methods for biodiesel production. Journal of the American Oil Chemists' Society, 2006. 83(5): p. 457-460.

210. Gomes, M.C.S., Pereira, N.C., de Barros, S.T.D., Separation of biodiesel and glycerol using ceramic membranes. Journal of Membrane Science, 2010. 352(1-2): p. 271-276.

211. Baroutian, S., Aroua, M.K., Raman, A.A.A., Sulaiman, N.M.N., A packed bed membrane reactor for production of biodiesel using activated carbon supported catalyst. Bioresource Technology, 2011. 102: p. 1095-1102.

212. Bauer, F., Hulteberg, C., Persson, T., Tamm, D., Biogas upgrading - review of commercial technologies, in SGC Rapport 2013:270, S. Swedish Gas Technology Centre, Editor 2013: Malmö, Sweden.

213. Aslam, M., Ahmad, R., Yasin, M., Khan, A.L., Shahid, M.K., Hossain, S., Khan, Z., Jamil, F., Rafiq, S., Bilad, M.R., Kim, J., Kumar, G., Anaerobic Membrane Bioreactors for Biohydrogen Production: Recent Developments, Challenges and Perspectives. Bioresource Technology, 2018. 269: p. 452-464.

214. Baker, R.W., Membrane Technology and Applications. Second Edition ed2012: John Wiley \& Sons Ltd.

215. Angelidaki, I., Treu, L., Tsapekos, P., Luo, G., Campanaro, S., Wenzel, H., Kougias, P.G., Biogas upgrading and utilization Current status and perspectives. Biotechology advances, 2018. 36: p. 452-466. 
216. Makaruk, A., Miltner, M., Harasek, M.,, Membrane biogas upgrading processes for the production of natural gas substitute. Separation and Purification Technology, 2010. 74(1): p. 83-92.

217. Aslam, M., McCarty, P.L., Bae, J., Kim, J., The effect of fluidized media characteristics on membrane fouling and energy consumption in anaerobic fluidized membrane bioreactors. Separation and Purification Technology, 2014. 132: p. 10-15.

218. Aslam, M., Lee, P-H., Kim, J., Analysis of membrane fouling with porous membrane filters by microbial suspensions for autotrophic nitrogen transformations. Separation and Purification Technology, 2015. 146: p. 284-293.

219. Aslam, M., Charfi, A., Lesage, G., Heran, M., Kim, J., Membrane bioreactors for wastewater treatment A review of mechanical cleaning by scouring agents to control membrane fouling. Chemical Engineering Journal, 2017. 307: p. 897-913.

220. Aslam, M., Ahmad, R., Kim, J., Recent developments in biofouling control in membrane bioreactors for domestic wastewater treatment. Separation and Purification Technology, 2018. 206: p. 297-315.

221. Orrego, D., Zapata-Zapata, A.D., Kim, D., Optimization and Scale-Up of Coffee Mucilage Fermentation for Ethanol Production. Energies, 2018. 11(4): p. 786.

222. Martinez-Saez, N., Ullate, M., Martin-Cabrejas, M.A., Martorell, P., Genovés, S., Ramon, D., del Castillo, M.D., A novel antioxidant beverage for body weight control based on coffee silverskin. Food Chemistry, 2014. 150: p. 227-234.

223. Fernandez-Gomez, B., Lezama, A., Amigo-Benavent, M., Ullate, M., Herrero, M., Martín, M.A., Mesa, M.D., del Castillo, M.D., Insights on the health benefits of the bioactive compounds of coffee silverskin extract. Journal of Functional Foods, 2016. 25: p. 197-207.

224. Oliveira, L.S., Franca, A.S., Camões, J.G.S., Oliveira, W.E., Low-cost adsorbents from chemically modified coffee husks for the treatment of wastewater containing heavy metals. Journal of Biotechnology, 2008. 136: p. S655.

225. Pandey, A., Soccol, C.R., Nigam, P., Brand, D., Mohan, R., Roussos, S., Biotechnological potential of coffee pulp and coffee husk for bioprocesses. Biochemical Engineering Journal, 2000. 6: p. 153-162.

226. Yadira, P.-S.B., Sergio, S-T., Fernando, S.E.L., Sebastian, P.J., Eapen, D., Bioethanol Production from Coffee Mucilage. Energy Procedia, 2014. 57: p. 950-956.

227. Shenoy, D., Pai, A., Vikas, R.K., Neeraja, H.S., Deeksha, J.S., Nayak, C., Rao, C.V., A study on bioethanol production from cashew apple pulp and coffee pulp waste. Biomass and Bioenergy, 2011. 35(10): p. 4107-4111.

228. Choi, I.S., Wi, S.G., Kim, S-B., Bae, H-J., Conversion of coffee residue waste into bioethanol with using popping pretreatment. Bioresource Technology, 2012. 125: p. 132-137.

229. Hernández, M.A., Rodríguez Susa, M.R., Andres, Y., Use of coffee mucilage as a new substrate for hydrogen production in anaerobic co-digestion with swine manure. Bioresource Technology, 2014. 168: p. 112-118. 
230. Battista, F., Fino, D., Mancini, G., Optimization of biogas production from coffee production waste. Bioresource Technology, 2016. 200: p. 884-890.

231. Corro, G., Pal, U., Cebada, S., Enhanced biogas production from coffee pulp through deligninocellulosic photocatalytic pretreatment. Energy Science \& Engineering, 2014. 2(4): p. 177-187.

232. Corro, G., Paniagua, L., Pal, U., Bañuelos, F., Rosas, M., Generation of biogas from coffee-pulp and cow-dung co-digestion: Infrared studies of postcombustion emissions. Energy Conversion and Management, 2013. 74: p. 471-481.

233. Juliastuti, S.R., Widjaja, T., Altway, A., Iswanto, T. Biogas production from pretreated coffee-pulp waste by mixture of cow dung and rumen fluid in co-digestion. in International Seminar on Fundamental and Application of Chemical Engineering 2016 (ISFAChE 2016). 2017. AIP Publishing. 